\title{
De afbakening van beroepsdomeinen van opleidingen in het middelbaar beroepsonderwijs
}

Citation for published version (APA):

Koeslag, M., \& van der Velden, R. K. W. (1996). De afbakening van beroepsdomeinen van opleidingen in het middelbaar beroepsonderwijs. Researchcentrum voor Onderwijs en Arbeidsmarkt, Faculteit der Economische Wetenschappen. ROA Reports No. 10 https://doi.org/10.26481/umarep.1996010

Document status and date:

Published: 01/01/1996

DOI:

10.26481/umarep.1996010

Document Version:

Publisher's PDF, also known as Version of record

\section{Please check the document version of this publication:}

- A submitted manuscript is the version of the article upon submission and before peer-review. There can be important differences between the submitted version and the official published version of record.

People interested in the research are advised to contact the author for the final version of the publication, or visit the DOI to the publisher's website.

- The final author version and the galley proof are versions of the publication after peer review.

- The final published version features the final layout of the paper including the volume, issue and page numbers.

Link to publication

\footnotetext{
General rights rights.

- You may freely distribute the URL identifying the publication in the public portal. please follow below link for the End User Agreement:

www.umlib.nl/taverne-license

Take down policy

If you believe that this document breaches copyright please contact us at:

repository@maastrichtuniversity.nl

providing details and we will investigate your claim.
}

Copyright and moral rights for the publications made accessible in the public portal are retained by the authors and/or other copyright owners and it is a condition of accessing publications that users recognise and abide by the legal requirements associated with these

- Users may download and print one copy of any publication from the public portal for the purpose of private study or research.

- You may not further distribute the material or use it for any profit-making activity or commercial gain

If the publication is distributed under the terms of Article $25 \mathrm{fa}$ of the Dutch Copyright Act, indicated by the "Taverne" license above, 


\section{De afbakening van beroependomeinen van opleidingen in het middelbaar beroepsonderwijs}

ROA-R-1996/10

M. Koeslag

R.K.W. van der Velden

Researchcentrum voor Onderwijs en Arbeidsmarkt

Faculteit der Economische Wetenschappen en Bedrijfskunde Rijksuniversiteit Limburg

Maastricht, mei 1996 
ISBN 90-5321-189-6 


\section{Inhoud}

Bladzijde

1 Inleiding 1

2 Data 5

3 Het analysemodel 9

3.1 Inleiding 9

3.2 Een maatstaf voor de overlap in beroependomein 9

$\begin{array}{ll}\text { 3.3 Analyse van de concurrentiestructuur } & 12\end{array}$

4 De positie van het middelbaar beroepsonderwijs op de arbeidsmarkt 15

$\begin{array}{ll}4.1 \text { Inleiding } & 15\end{array}$

4.2 Concurrenten van de opleidingen in het middelbaar beroepsonderwijs $\quad 15$

$\begin{array}{ll}4.3 \text { De concurrentiestructuur op de arbeidsmarkt } & 18\end{array}$

5 De afbakening van beroependomeinen van opleidingen in het middelbaar beroepsonderwijs $\quad 25$

5.1 Inleiding $\quad 25$

5.2 De sector landbouw $\quad 27$

5.3 De sector techniek $\quad 28$

5.4 De sector economie $\quad 30$

5.5 De sector dienstverlening en gezondheidszorg 31

6 Samenvatting 33

$\begin{array}{ll}\text { Literatuur } & 37\end{array}$

Bijlage 1 Ondervonden concurrentie en beroepenspreiding van opleidingen in het middelbaar beroepsonderwijs

Bijlage 2 De belangrijkste concurrenten van de opleidingen in het middelbaar beroepsonderwijs

Bijlage 3 Indeling opleidingen naar segment

Bijlage 4 Clusters van opleidingen in het middelbaar beroepsonderwijs

Bijlage 5 Huidige opleidingsstructuur in het middelbaar beroepsonderwijs 


\section{Inleiding}

Vanaf het begin van de jaren ' 80 is het overheidsbeleid ten aanzien van het secundair beroepsonderwijs sterk gericht geweest op de verbetering van de aansluiting met de arbeidsmarkt. Dit beleid steunde op twee pijlers. De eerste pijler betreft het streven om het bedrijfsleven in sterkere mate dan voorheen te betrekken bij de inhoud en vormgeving van het onderwijs. Dit zou zowel een adequate aansluiting tussen opleiding en beroepspraktijk moeten waarborgen als ook de medeverantwoordelijkheid van het bedrijfsleven voor de inhoud van het beroepsonderwijs tot uitdrukking moeten brengen. De grotere betrokkenheid van het bedrijfsleven kreeg organisatorisch gestalte via de instelling van BOOB's (Bedrijfstakgewijs Overleg Onderwijs Bedrijfsleven) die tot taak hadden om op basis van door de sociale partners vastgestelde beroepsprofielen te komen tot opleidingsprofielen en eindtermen voor het MBO. Met de invoering van de Wet Educatie en Beroepsonderwijs (WEB) per 1 januari 1996 is deze taak toebedacht aan de Landelijke Organen Beroepsonderwijs (LOB's), waarin de voormalige BOOB's zijn gefuseerd met de landelijke organen voor het leerlingwezen.

De tweede pijler onder het beleid betreft de vergroting van de herkenbaarheid van de opleidingen en de transparantie van de opleidingenstructuur. Dit krijgt gestalte in de formulering van herkenbare opleidingsprofielen en eindtermen. In dit verband moet vooral gewezen worden op de ontwikkeling naar een landelijke kwalificatiestructuur voor het secundair beroepsonderwijs. De landelijke kwalificatiestructuur kan worden omschreven als 'het geordend en samenhangend geheel van op eindtermen gebaseerde kwalificaties en deelkwalificaties welke voor het secundair beroepsonderwijs worden onderscheiden' (OC \& W, 1994). Doelstellingen van de kwalificatiestructuur zijn onder meer het vergroten van de transparantie van opleidingen, het vergroten van de samenhang tussen opleidingen, het vermijden van ondoelmatige overlap, het vergroten van horizontale en verticale doorstroommogelijkheden en het verminderen van ongekwalificeerde tussentijdse uitstroom.

Belangrijke elementen in deze kwalificatiestructuur zijn het 'format', het 'raamwerk' en de 'eindtermen'. Het format heeft betrekking op de ordeningsprincipes. Het geeft het indelingschema waarlangs de kwalificaties en deelkwalificaties geordend worden. Het format onderscheidt vier uniforme niveaus: assistentopleiding (niveau 1), basisberoepsopleiding (niveau 2), vakopleiding (niveau 3) en middenkader of specialistenopleiding (niveau 4). Bij elk van deze niveaus hoort een nominaal aantal studiebelastingsuren. Verder stelt het format eisen ten aanzien van de breedte van de opleidingen en het soort kwalificaties waarvoor de opleidingen voorbereiden. Deze moeten niet alleen kwalificeren voor een beroep, maar ook kwalificeren voor vervolgonderwijs (doorstroomkwalificaties) en de maatschappij (maatschappelijke en 
culturele kwalificaties). Het format heeft betrekking op zowel de opleidingen in het initieel middelbaar beroepsonderwijs, als de opleidingen in het leerlingwezen, terwijl ook niet door de rijksoverheid bekostigde opleidingen in de systematiek kunnen worden ingepast.

Op basis van het format zal een herijking plaatsvinden van de bestaande opleidingen. Eerst zal een raamwerk ontwikkeld worden waarin het geheel van de opleidingen c.q. kwalificaties herordend danwel nieuw ontwikkeld wordt. Een belangrijke doelstelling van dit raamwerk is om ondoelmatige overlap te voorkomen en via een herschikking tot een beperking van het aantal bestaande opleidingen te komen. Nadat dit raamwerk is vastgesteld zal een nadere invulling plaatsvinden van de specifieke eindtermen.

De Landelijke Organen Beroepsonderwijs spelen bij deze herijking een belangrijke rol. Om de discussie over deze herijking goed te kunnen voeren is het van belang dat deze organen beschikken over feitelijke informatie omtrent de arbeidsmarktpositie van de huidige opleidingen in het middelbaar beroepsonderwijs en over de feitelijke overlap in beroependomeinen. Voor alle duidelijkheid, de term beroependomein verwijst hier naar de soort beroepen waarin schoolverlaters van een bepaalde opleiding feitelijk werkzaam zijn. In die zin onderscheidt het zich van het meer ingeburgerde begrip beroepsprofiel, dat verwijst naar de voor een specifiek beroep benodigde kennis en vaardigheden. Bovendien wordt het begrip beroependomein in deze studie geoperationaliseerd aan de hand van de feitelijke beroepen waarin schoolverlaters terechtkomen, en dus niet op basis van het beoogde beroepenveld waartoe de opleiding voorbereidt.

Een analyse van het feitelijke beroependomein van een opleiding en de eventuele overlap met andere opleidingen kan mede een basis vormen voor een inhoudelijke discussie over gewenste kwalificaties en eindtermen. Tegen deze achtergrond heeft het Instituut voor Onderzoek van het Onderwijs (SVO) in het najaar van 1995 aan het Researchcentrum voor Onderwijs en Arbeidsmarkt (ROA) opdracht verleend een verkennend onderzoek te verrichten op basis van bij het ROA beschikbare schoolverlatersgegevens.

Momenteel worden door het ROA twee grootschalige schoolverlatersonderzoeken uitgevoerd: 'Registratie van Uitstroom en Bestemming van Schoolverlaters' (RUBS) onder schoolverlaters van de eerste en tweede fase van het voortgezet onderwijs en de 'HBO-Monitor' onder afgestudeerden van het hoger beroepsonderwijs. De opleidingen in het kader van het leerlingwezen en in-service onderwijs ontbreken 
vooralsnog in deze schoolverlatersonderzoeken ${ }^{1}$. Dit impliceert dat het voorliggende onderzoek uitsluitend betrekking heeft op de voltijd opleidingen in het middelbaar beroepsonderwijs.

Als een nadere uitwerking van de onderzoeksopdracht zijn de volgende onderzoeksvragen geformuleerd:

1. Op welke wijze kan de overlap in beroependomeinen tussen verschillende opleidingen in kaart worden gebracht?

2. Wat is de concurrentiepositie van de huidige opleidingen in het voltijd middelbaar beroepsonderwijs ten opzichte van andere opleidingen (met name in het voorbereidend en hoger beroepsonderwijs)?

3. Welke opleidingen in het voltijd middelbaar beroepsonderwijs hebben een 'eigen' beroependomein en bij welke opleidingen is sprake van overlap met andere (K)MBO-opleidingen?

In het voorliggend rapport wordt verslag gedaan van dit verkennend onderzoek. Het rappport is als volgt opgebouwd. Hoofdstuk 2 geeft een beschrijving van de gebruikte data. Hoofdstuk 3 gaat nader in op de vraag op welke wijze de overlap in beroependomeinen tussen opleidingen kan worden vastgesteld. Voorts wordt hier een methodiek ontwikkeld om de concurrentiestructuur tussen opleidingen te bepalen en op basis daarvan te komen tot een clustering van onderling samenhangende opleidingen. In hoofdstuk 4 wordt een nadere analyse gemaakt van de positie van de (K)MBO opleidingen ten opzichte van andere opleidingen, met name de opleidingen in het VBO en HBO. Vervolgens wordt in hoofdstuk 5 nagegaan welke opleidingen in het middelbaar beroepsonderwijs een eigen beroependomein hebben en welke opleidingen overlap in beroependomein vertonen. In hoofdstuk 6 worden de voornaamste resultaten nog eens kort samengevat.

1. In de meting van 1994 heeft wel een pilot plaatsgevonden onder schoolverlaters van het Beroepsbegeleidend Onderwijs (BBO). Deze had echter een beperkte omvang. De bedoeling is het schoolverlatersonderzoek wel uit te breiden met een specifiek monitoringinstrument voor het $\mathrm{BBO}$. 



\section{Data}

De bestanden die gebruikt zijn om de overlap in beroependomeinen van opleidingen in kaart te brengen, hebben betrekking op een tweetal grootschalige surveys die door het ROA worden uitgevoerd: RUBS en HBO-Monitor. RUBS (Registratie van Uitstroom en Bestemming van Schoolverlaters) betreft een jaarlijkse landelijke survey onder gediplomeerde en ongediplomeerde schoolverlaters uit het AVO, VBO en $(\mathrm{K}) \mathrm{MBO}^{2}$. RUBS geeft informatie over de bestemming van deze schoolverlaters in het vervolgonderwijs en op de arbeidsmarkt, over de kansen op het vinden van werk en over de aansluiting tussen verworven en vereiste kwalificaties. Het onderzoek vindt plaats door middel van een schriftelijke vragenlijst zo'n driekwart jaar na het verlaten van de opleiding. De HBO-Monitor is een vergelijkbare survey onder afgestudeerden uit het hoger beroepsonderwijs ${ }^{3}$. De meting in dit onderzoek vindt plaats ruim één jaar na het verlaten van de opleiding.

Voor de analyses in dit rapport zijn twee analysebestanden aangelegd (zie schema 2.1).

Schema 2.1

Overzicht analysebestanden

\begin{tabular}{|c|c|c|}
\hline & $\begin{array}{l}\text { Analyse positie }(\mathrm{K}) \mathrm{MBO} \\
\text { t.o.v. andere opleidingen }\end{array}$ & $\begin{array}{l}\text { Analyse overlap } \\
\text { opleidingen (K)MBO }\end{array}$ \\
\hline Bestand & RUBS 93, HBO Monitor 93 & $\begin{array}{l}\text { RUBS 92, RUBS } 93 \\
\text { RUBS } 94\end{array}$ \\
\hline Populatie & $\begin{array}{l}\text { gedipl. werkende schoolverlaters } \\
\text { uit het VBO, AVO, KMBO, MBO } \\
\text { en HBO uit het schooljaar 1991/92 }\end{array}$ & $\begin{array}{l}\text { gedipl. werkende schoolverlaters } \\
\text { uit KMBO en MBO opleidingen } \\
\text { uit de schooljaren 1990/91, 1991/92, } \\
1992 / 93\end{array}$ \\
\hline Aantal cases & 16.000 & 21.000 \\
\hline
\end{tabular}

2. Het RUBS-onderzoek wordt uitgevoerd met subsidie van de Ministeries van Onderwijs, Cultuur en Wetenschappen en Landbouw, Natuurbeheer en Visserij en het Landelijk Dienstverlenend Centrum voor Studie- en Beroepskeuzevoorlichting (LDC). Het onderzoek wordt uitgevoerd in samenwerking met DESAN Marktonderzoek. Voor een uitvoerige beschrijving van de hier gebruikte data, zie Wieling, Van de Loo en Van der Velden (1993), Van Smoorenburg et. al. (1994) en Van Smoorenburg en Van der Velden (1995a).

3. De HBO-Monitor wordt uitgevoerd in opdracht van de HBO-Raad in samenwerking met DESAN Marktonderzoek. Voor een uitvoerige beschrijving van de hier gepresenteerde data, zie Van de Loo en Van der Velden (1994). 
Ten behoeve van de analyse van de positie van het (K)MBO op de arbeidsmarkt voor schoolverlaters (hoofdstuk 4 ) is een analysebestand gecreëerd dat een koppeling betreft van RUBS én HBO-Monitor. Daarbij is gebruik gemaakt van de meting die in $1993^{4}$ heeft plaatsgevonden onder gediplomeerde schoolverlaters van het AVO, VBO, KMBO, MBO of HBO. Voor het analysebestand zijn uitsluitend de schoolverlaters geselecteerd die op het moment van de meting een beroep uitoefenen. Deze selectie leidde tot een analysebestand van bijna 16.000 cases. De betreffende respondenten zijn afkomstig uit 258 verschillende opleidingen. Hiervan behoren 35 opleidingen tot het VBO, 17 tot het KMBO, 77 tot het MBO en 121 tot het $\mathrm{HBO}$.

Ten behoeve van de analyse naar de overlap tussen opleidingen in het middelbaar beroepsonderwijs (hoofdstuk 5) is gebruik gemaakt van drie opeenvolgende metingen van RUBS, te weten de metingen uit 1992, 1993 en 1994. Van deze metingen zijn de respondenten geselecteerd die:

a. een opleiding in het KMBO of MBO hebben verlaten

b. een diploma van deze opleiding hebben en

c. op het moment van de enquête een beroep uitoefenen.

Deze selectie leidt tot een bestand van 21.000 cases. De betreffende schoolverlaters zijn afkomstig uit 187 verschillende opleidingen, waarvan 32 tot het KMBO gerekend kunnen worden en 155 tot het MBO.

Voor de analyses in dit onderzoek zijn beide analysebestanden opgehoogd naar landelijke aantallen gediplomeerde schoolverlaters. Deze populatie aantallen zijn in het geval van RUBS geschat op basis van de Integrale LeerlingTelling van het Ministerie van Onderwijs, Cultuur en Wetenschappen en aanvullende gegevens van het Ministerie van Landbouw, Natuurbeheer en Visserij. Bij de HBO-Monitor is gebruik gemaakt van het CRIHO-bestand.

Van elke case in beide analysebestanden is zowel de gevolgde opleiding geregistreerd als het beroep. Voor beide variabelen is uitgegaan van de meest verfijnde informatie die beschikbaar is. De reden hiervoor is dat enerzijds overlap tussen opleidingen te maken heeft met het feit dat vergelijkbare opleidingen soms onder een verschillende naam opereren. Om die overlap te laten zien is het zinvol deze opleidingen als aparte opleidingen te beschouwen en niet bij voorbaat reeds

4. De reden om niet de meting 1994, maar de meting 1993 te nemen voor dit onderzoek heeft te maken met het feit dat in de meting 1994 bij RUBS de 'oude' CBS Beroepenclassificatie 1984 is gebruikt, terwijl bij de meting HBO-Monitor is overgestapt naar de 'nieuwe' CBS Standaardberoepenclassificatie 1992. Beide classificaties kunnen echter niet één-op-één gekoppeld worden. De meting 1995 was op het moment van de analyse nog niet beschikbaar. 
samen te nemen. Anderzijds kan het voorkomen dat twee opleidingen ogenschijnlijk een gemeenschappelijk beroependomein hebben. Dit kan echter een artefact zijn van het aggregatieniveau waarop het beroep is gemeten. Hoe hoger dit aggregatieniveau, hoe groter de overlap zal zijn ${ }^{5}$.

Bij de opleidingen is uitgegaan van de opleidingenclassificatie die het ROA ontworpen heeft voor de schoolverlatersonderzoeken RUBS en HBO-Monitor. De basis voor deze classificatie wordt gevormd door de opleidingsindelingen in de Integrale LeerlingTelling en de HBO-almanak ${ }^{6}$. Indien onderwijsinstellingen opleidingen aanbieden die afwijken van de in deze bronnen genoemde opleidingen, dan worden deze als aparte opleiding toegevoegd ${ }^{7}$.

Bij de indeling in beroepen is in de betreffende metingen gebruik gemaakt van de CBS Beroepenclassificatie $1984^{8}$. De beroepen zijn gecodeerd op het meest verfijnde 4-digit niveau. Voor een aantal beroepen is deze indeling echter nog niet verfijnd genoeg. Daarom is een $5 \mathrm{e}$ digit toegevoegd om waar nodig relevante beroepen nader te kunnen differentiëren. Deze toevoeging van extra beroepen is geschied in overleg met sectordeskundigen. In totaal worden in de analysebestanden meer dan 700 verschillende beroepen onderscheiden.

5. Een goed voorbeeld betreft het beroep jeugdleider e.d. Hieronder worden uiteenlopende beroepen verstaan als groepsleider, cultureel werker en creatief therapeut, waarvoor in het HBO drie verschillende opleidingen bestaan.

6. Op dit moment wordt overigens gewerkt aan een nieuwe systematische opleidingenclassificatie waar ook andere bronnen bij gebruikt worden.

7. Het aantal te onderscheiden opleidingen in het HPO is dermate groot dat hier een indeling in studieclusters in plaats van opleidingsrichtingen is gehanteerd. Verwacht mag overigens worden dat gelet op de bevoegdheidseisen die aan HPO afgestudeerden in het onderwijs worden gesteld concurrentie tussen opleidingsrichtingen nauwelijks zal voorkomen.

8. Inmiddels is overgestapt op de nieuwe Standaard Beroepen Classificatie 1992. 



\section{Het analysemodel}

\subsection{Inleiding}

In dit hoofdstuk zal ingegaan worden op het analysemodel. Centrale vraagstelling in het onderzoek is op welk wijze de overlap in beroependomeinen tussen verschillende opleidingen kan worden vastgesteld. We kunnen dit ook interpreteren als de mate waarin opleidingen onderling concurreren op de arbeidsmarkt. Opleidingen waarvan het beroependomein een sterke overlap vertoont ondervinden veel concurrentie van elkaar, terwijl opleidingen die geen enkele overlap in beroependomein vertonen geen concurrentie van elkaar ondervinden. In paragraaf 3.2 wordt nader ingegaan op de wijze waarop de overlap in beroependomein c.q. de concurrentie tussen twee opleidingen kan worden vastgesteld. Tevens zal worden aangegeven dat er een verband bestaat tussen de concurrentie die een opleiding van andere opleidingen op de arbeidsmarkt ondervindt en de range van beroepen waartoe de opleiding voorbereidt. In het tweede deel van het hoofdstuk, paragraaf 3.3, zal een methode worden gepresenteerd om de concurrentiestructuur van opleidingen in kaart te brengen. Aan de hand van deze methodiek kan bepaald worden welke opleidingen een min of meer gemeenschappelijk beroependomein hebben.

\subsection{Een maatstaf voor de overlap in beroependomein}

ledere opleiding kan getypeerd worden aan de hand van haar beroependomein: de verdeling van schoolverlaters over de beroepen op de arbeidsmarkt. Wanneer de arbeidsmarkt bestaat uit bijvoorbeeld 20 beroepen, dan toont het beroependomein van een opleiding de proportie schoolverlaters van de betreffende opleiding in elk van deze 20 beroepen. Dit beroependomein varieert per opleiding en kan breed of juist smal zijn. Opleidingen hebben een breed beroependomein wanneer de schoolverlaters sterk verspreid over de verschillende beroepen op de arbeidsmarkt terechtkomen. Bijvoorbeeld wanneer in alle 20 beroepen een gelijke proportie schoolverlaters van de opleiding is terechtgekomen. Vindt het merendeel van de schoolverlaters echter een baan in slechts één (of enkele) beroep(en), dan heeft de opleiding een smal beroependomein.

Het beroependomein van een opleiding is het uitgangspunt bij de ontwikkeling van een maatstaf voor concurrentie of overlap in beroependomein. Een opleiding concurreert met een andere opleiding op de arbeidsmarkt, wanneer er tenminste éen beroep is waarin de schoolverlaters van beide opleidingen een baan hebben gevonden. Vanwege dit beroep, vertonen de beroependomeinen van de twee 
opleidingen een (gedeeltelijke) overlap. Hoe groter de overlap in beroependomein tussen twee opleidingen, hoe groter de concurrentie tussen deze opleidingen.

Borghans (1992) laat zien dat de kans dat een schoolverlater van opleiding i en een schoolverlater van opleiding $\mathrm{j}$ elkaar treffen in hetzelfde beroep gedefinieerd kan worden als:

$$
K(i, j)=\sum_{b} P_{i}^{b} P_{j}^{b}
$$

waarbij:

$P_{i}^{b}=$ de proportie van schoolverlaters uit opleiding $i$ die een baan hebben gevonden in beroep $b$, en

$P_{j}^{b}=$ de proportie van schoolverlaters uit opleiding $j$ die een baan hebben gevonden in beroep $b$.

De concurrentie tussen twee opleidingen (opleiding i en j) kan nu volgens Borghans (1992) gedefinieerd worden als de mate waarin de opleidingen eenzelfde beroependomein hebben. De kans dat de opleidingen eenzelfde beroependomein hebben (de concurrentie-index SIM(i,j)) wordt bepaald door de kans dat de schoolverlaters van opleiding $i$ in een beroep schoolverlaters van opleiding $j$ treffen $(K(i, j))$, waarbij een correctie plaatsvindt voor de spreiding van $i$ en $j$ over de beroepen (de termen $\mathrm{K}(\mathrm{i}, \mathrm{i})$ en $\mathrm{K}(\mathrm{j}, \mathrm{j})$ in de noemer):

$$
\operatorname{SIM}(i, j)=\frac{K(i, j)}{\sqrt{K(i, i) K(j, j)}}
$$

De concurrentie-index is 1 , wanneer de twee opleidingen een identiek beroependomein hebben. Dit betekent dat de schoolverlaters van opleiding i, met gelijke proporties in dezelfde beroepen werkzaam zijn als de schoolverlaters van opleiding $j$, en dus elkaar altijd zullen treffen op de arbeidsmarkt. De maatstaf is nul wanneer de schoolverlaters van beide opleidingen elkaar in geen enkel beroep op de arbeidsmarkt treffen.

De totale concurrentie die een opleiding ondervindt van alle andere opleidingen op de arbeidsmarkt, kan nu gedefinieerd worden als de mate waarin het beroependomein van de opleiding overeenkomst vertoont met de beroependomeinen van alle 
andere opleidingen, waarbij gecorrigeerd wordt voor de grootte van de opleidingen (Borghans, Van der Velden en Wiendels, 1996). De totale concurrentie $\mathrm{CONC}_{\mathrm{i}}$ die opleiding $\mathrm{i}$ ondervindt van alle andere opleidingen $\mathrm{j}$ wordt gedefinieerd als:

$$
\operatorname{CONC}_{i}=\sum_{j} \operatorname{SIM}(i, j) * \frac{W P(j)}{B B}
$$

waarbij:

$W P(j)=$ het aantal werkzame personen met opleiding $j$, en

$\mathrm{BB}=$ het aantal werkzame personen uit alle opleidingen samen

De overlap in beroependomein van een opleiding met andere opleidingen is afhankelijk van de breedte van het beroependomein van de opleiding. Naarmate de opleiding een breder beroependomein heeft, is de kans groter dat de opleiding overlap vertoont met andere opleidingen. Schoolverlaters van een brede opleiding komen in een breed scala van beroepen op de arbeidsmarkt terecht, en hebben zodoende relatief veel kansen om schoolverlaters van andere opleidingen te treffen. Een maatstaf voor de breedte van het beroependomein van een opleiding is de Gini-Hirschmann coëfficiënt (Warnken, 1986). Deze Gini-Hirschmann coëfficiënt wordt gedefinieerd als (De Grip en Heijke, 1989):

$$
G H_{i}=\left(1-K(i, i) * \frac{B}{B-1}\right)
$$

waarbij geldt dat:

$\mathrm{GH}_{\mathrm{i}}=$ de breedte van het beroependomein van opleiding $\mathrm{i}$,

$K(i, i)=$ de kans dat de schoolverlaters van opleiding $i$ elkaar treffen in hetzelfde beroep, en

$B=$ het aantal beroepen op de arbeidsmarkt.

Wanneer een opleiding een smal beroependomein heeft, is $\mathrm{GH}_{\mathrm{i}}$ klein en is $\mathrm{K}(\mathrm{i}, \mathrm{i})$ groot. Uit (2) en (3) volgt dat in dat geval de hoeveelheid ondervonden concurrentie ook geringer wordt. 


\subsection{Analyse van de concurrentiestructuur}

In deze paragraaf staat de vraag centraal hoe de concurrentiestructuur tussen verschillende opleidingen op de arbeidsmarkt in kaart kan worden gebracht. Op welke manier kan aangegeven worden welke opleidingen een overlappend beroependomein hebben en welke opleidingen juist een geheel eigen beroependomein hebben? De methode die hiervoor zal worden gebruikt is clusteranalyse.

Uitgangspunt van de clusteranalyse is een matrix opleiding $\mathrm{x}$ beroep, waarin de rijen refereren naar de opleidingen en de kolommen naar de beroepen. ledere rij indiceert het beroependomein van de betreffende opleiding. Opleidingen die eenzelfde beroependomein hebben worden samengevoegd in clusters. Door te streven naar een grote homogeniteit binnen clusters en weinig samenhang tussen clusters, kan op deze wijze tot een indikking van het aantal opleidingen worden gekomen.

Bij het clusteren van opleidingen wordt het beroependomein van iedere opleiding voorgesteld als een vector in een multidimensionele ruimte. Bij het identificeren van clusters wordt de onderlinge afstand tussen de vectoren weergegeven aan de hand van een overeenkomst-maatstaf. Deze overeenkomst-maatstaf is dezelfde als de concurrentie-index uit paragraaf 3.2 waarin de overeenkomst in beroependomein tussen twee opleidingen tot uitdrukking wordt gebracht.

De overeenkomst-maatstaf is weer te geven aan de hand van de cosinus van de hoek van twee vectoren. Wanneer twee opleidingen soortgelijke beroependomeinen hebben, lopen de vectoren (= de beroependomeinen) evenwijdig aan elkaar: de cosinus van de hoek en de mate van overeenkomst is dan gelijk aan 1. Naarmate de beroependomeinen van de opleidingen meer uiteenlopen, wordt de hoek tussen de vectoren groter en nadert de cosinus en de mate van overeenkomst de waarde 0 .

Het clusteren van de opleidingen gaat als volgt: eerst wordt de mate van overeenkomst tussen ieder paar opleidingen in de matrix opleiding $x$ beroep bepaald. De opleidingen met de grootste overeenkomst wat betreft beroependomein worden als één nieuw element (cluster) in de matrix opgenomen. Vervolgens wordt opnieuw de mate van overeenkomst tussen ieder paar opleidingen in de nieuwe matrix opleiding $x$ beroep bepaald, en worden de opleidingen (of clusters) met de grootste overeenkomst in beroependomein samengenomen tot één cluster. Dit proces herhaalt zich in beginsel totdat alle opleidingen zijn samengevoegd tot één cluster. 
Bij het proces van clusteren kunnen verschillende algoritmen worden gehanteerd (Aldenderfer \& Blashfield, 1984). In dit onderzoek is de mate van overeenkomst tussen opleidingen gemeten met behulp van de 'average-linkage' methode. Met behulp van deze methode wordt een opleiding pas aan een cluster toegevoegd, wanneer het beroependomein van de opleiding het beste lijkt op de gemiddelde overeenkomst van beroependomeinen van alle opleidingen die zich al in het cluster bevinden. Deze maatstaf houdt er rekening mee dat de afstand van een case in een cluster naar iedere andere case in dat cluster kleiner is dan de afstand naar een case die niet tot dit cluster behoort. De afstand tussen twee clusters wordt berekend door het gemiddelde te nemen van alle mogelijke combinaties van paren uit het eerste en het tweede cluster.

De 'average-linkage' methode heeft als nadeel dat elke opleiding even zwaar meetelt in de analyse, ook al is die op weinig waarnemingen gebaseerd. In de analyse zal de robuustheid van de resultaten worden getoetst door de analyse te herhalen voor opleidingen waarvan een minimum aantal schoolverlaters in het onderzoeksbestand zitten.

Eerder is al aangegeven dat het clusterproces zich in beginsel herhaalt totdat alle opleidingen zijn samengevoegd tot één cluster. Uiteraard is het niet de bedoeling van deze analyse om alle opleidingen bij elkaar te voegen, maar juist te komen tot een zekere indikking van het aantal opleidingen. Opleidingen met veel verwantschap worden daartoe samengevoegd. Dit proces moet afgebroken worden op het moment dat twee opleidingen bij elkaar worden gevoegd die onderling te weinig verwantschap vertonen. Hiervoor worden twee criteria gebruikt, een statistisch en een inhoudelijk criterium. Het statistisch criterium is gebaseerd op de afname in de overeenkomst-maatstaf. Bij elke stap in het clusterproces neemt deze coëfficiënt af. Het clusterproces wordt afgebroken wanneer de twee betreffende opleidingen op grond van de overeenkomst-maatstaf te weinig verwantschap vertonen (dat wil zeggen dat de mate van overeenkomst minder dan $35 \%$ bedraagt). Omdat dit criterium in de praktijk niet altijd een duidelijke demarcatie oplevert, wordt daarnaast ook nog inhoudelijk naar het clusterproces gekeken. Het clusterproces wordt in dat geval afgebroken wanneer twee opleidingen worden samengevoegd die inhoudelijk te weinig verwantschap hebben. 



\section{De positie van het middelbaar beroepsonderwijs op de arbeidsmarkt}

\subsection{Inleiding}

In dit hoofdstuk zal een analyse worden gegeven van de positie van de opleidingen in het middelbaar beroepsonderwijs (KMBO en $\mathrm{MBO}$ ) ten opzichte van andere opleidingen, met name de opleidingen in het voorbereidend beroepsonderwijs (VBO) en hoger beroepsonderwijs (HBO). Hierbij worden twee invalshoeken onderscheiden. In de eerste plaats zal vanuit het perspectief van de (K)MBO opleiding naar de concurrentie met andere opleidingen worden gekeken. In paragraaf 4.2 wordt nader ingegaan op de belangrijkste concurrenten van de opleidingen in het KMBO en MBO. In de tweede plaats zal een nadere analyse plaatsvinden van de concurrentiestructuur op de arbeidsmarkt. Op basis van deze concurrentiestructuur zal in paragraaf 4.3 een typering plaatsvinden van de segmenten waarvoor de opleidingen voorbereiden.

\subsection{Concurrenten van de opleidingen in het middelbaar beroepsonderwijs}

In deze paragraaf wordt een nadere analyse gegeven van de belangrijkste concurrenten van de opleidingen in het KMBO en MBO. Daarbij wordt gebruik gemaakt van de metingen die in 1993 hebben plaatsgevonden onder schoolverlaters van het VBO, AVO, MBO en HBO.

Opleidingen kunnen getypeerd worden naar zowel de concurrentie die ze ondervinden van andere opleidingen als naar de breedte van het beroependomein. Zoals in hoofdstuk 3 reeds is aangegeven bestaat tussen beide grootheden een relatie. Enerzijds zijn er opleidingen die hun studenten voorbereiden op heel specifieke beroepen. In dergelijke opleidingen worden vaardigheden bijgebracht die vrijwel uitsluitend van nut zijn op een sterk afgebakend deel van de arbeidsmarkt. Vanwege deze specifieke beroepsvoorbereiding hebben de betreffende schoolverlaters wel een zekere voorsprong op andere schoolverlaters. De verwachting is daarom dat schoolverlaters van deze opleidingen nauwelijks concurrentie ondervinden van andere opleidingen. De keerzijde is evenwel dat men sterk afhankelijk is van de werkgelegenheidsontwikkelingen in het eigen beroependomein.

Anderzijds zijn er opleidingen die hun studenten niet specifiek voorbereiden voor een bepaald beroep, maar juist vaardigheden bijbrengen waarmee ze in een relatief breed scala van beroepen een baan kunnen vinden. Deze opleidingen worden gekenmerkt door een relatief breed beroependomein. Vanwege de generieke aard 
van de beroepsvoorbereiding kan worden verwacht dat schoolverlaters van deze opleidingen relatief veel concurrentie ondervinden van andere opleidingen, omdat ze op geen enkel terrein een exclusieve voorsprong hebben. Daar staat tegenover dat men relatief makkelijk kan uitwijken naar andere delen van de arbeidsmarkt.

Hier tekent zich het dilemma af waar veel opleidingen zich voor geplaatst zien. Enerzijds kan men opteren voor een sterke mate van specialisatie in de opleiding. Hierdoor worden de productieve vaardigheden van de studenten weliswaar sterk vergroot, maar deze kunnen slechts op een beperkt deel van de arbeidsmarkt aangewend worden. Anderzijds kan men kiezen voor een brede opleiding waardoor schoolverlaters veel uitwijkmogelijkheden hebben, echter met het risico dat men ook veel concurrentie ondervindt van opleidingen die hun studenten juist wel specifiek voorbereiden.

Vanuit een macro optiek is het overigens niet wenselijk dat elke opleiding zich in dezelfde mate specialiseert. Voor een optimaal functioneren van de arbeidsmarkt is het waarschijnlijk te prefereren dat - naast specialistische opleidingen die zich richten op een beperkt beroependomein - er ook generieke opleidingen zijn die de niches in de arbeidsmarkt vullen.

Tabel 4.1

De ondervonden concurrentie en beroepenspreiding van $\mathrm{KMBO}$ en $\mathrm{MBO}$ opleidingen

\begin{tabular}{lrrrr}
\hline & \multicolumn{4}{c}{ Beroepenspreiding } \\
Concurrentie & $\begin{array}{r}\text { Laag } \\
\%\end{array}$ & $\begin{array}{r}\text { Gemiddeld } \\
\%\end{array}$ & $\begin{array}{r}\text { Hoog } \\
\%\end{array}$ & $\mathrm{~N}$ \\
& & & & \\
\hline Laag & 87.5 & 17.6 & 11.1 & 12 \\
Gemiddeld & 12.5 & 52.9 & 27.8 & 15 \\
Hoog & 0.0 & 29.4 & 61.1 & 16 \\
Totaal $(\mathrm{N}=100 \%)$ & 8 & 17 & 18 & 43 \\
\hline
\end{tabular}

Voor de opleidingen in het $\mathrm{KMBO}$ en $\mathrm{MBO}$ is zowel de breedte van het beroependomein bepaald als de hoeveelheid concurrentie die de opleiding van andere opleidingen ondervindt. In bijlage 1 wordt de typering van de verschillende onderscheiden opleidingen gepresenteerd ${ }^{9}$. In tabel 4.1 is de relatie tussen beide

9. Deze kwalitatieve typering is gemaakt met behulp van de methode van symmetrische grenzenindeling (Wieling, De Grip, Willems (1990)). Dit resulteert bij de Gini-Hirschmann coëfficiënt in de volgende grenzen: erg laag: $\leq 0.353,0.354<$ laag $\leq 0.543,0.544<$ gemiddeld $\leq 0.806,0.807<$ hoog $\leq 0.997$, erg hoog: $>0.997$. Bij de concurrentiemaatstaf is de typering gebaseerd op de volgende grenzenindeling: erg laag: $\leq 0.01,0.02<$ laag $\leq$ 
grootheden weergegeven. Voor de overzichtelijkheid zijn beide maatstaven in drie klassen ingedeeld. In de tabel zijn opleidingen die met minder dan 25 cases in het bestand vertegenwoordigd zijn buiten beschouwing gelaten. Deze opleidingen zijn overigens bij de berekening van de kwalitatieve typering wel meegenomen.

Bij de opleidingen in het KMBO en MBO lijkt de eerder geschetste relatie tussen de breedte van het beroependomein en de ondervonden concurrentie vanuit andere opleidingen duidelijk op te gaan. De opleidingen met een smal beroependomein ondervinden relatief weinig concurrentie van andere opleidingen, terwijl de opleidingen met een relatief breed beroependomein relatief vaak concurrentie ondervinden van andere opleidingen.

In het KMBO zijn het vooral de verzorgende en administratieve opleidingen die gekenmerkt worden door een breed beroependomein en een hoge mate van concurrentie (zie bijlage 1). De opleiding motorvoertuigentechniek wordt daarentegen gekenmerkt als een opleiding met een smal beroependomein en weinig ondervonden concurrentie.

Op MBO-niveau zijn de meeste agrarische en technische opleidingen te typeren als richtingen met een relatief breed beroependomein. De ondervonden concurrentie verschilt evenwel sterk per opleiding. De opleiding bouwkunde ondervindt weinig concurrentie, terwijl de opleiding elektrotechniek relatief veel concurrentie ondervindt. De laboratoriumopleidingen worden vooral gekenmerkt door een lage ondervonden concurrentie. De detailhandelopleidingen en de economisch administratieve opleidingen worden gekenmerkt door zowel een grote beroepenspreiding als een hoge ondervonden concurrentie. Bij de gezondheidszorgopleidingen varieert de breedte van het beroependomein van (erg) laag bij de opleidingen 'assistenten gezondheidszorg', 'aktiviteitenbegeleiding', 'sport en beweging' en 'haarverzorging' tot gemiddeld bij de overige opleidingen. De ondervonden concurrentie vanuit andere opleidingen is hiermee in lijn: variërend van laag bij de opleidingen met een smal beroependomein tot gemiddeld of hoog bij de opleidingen met een gemiddelde beroepenspreiding.

Bijlage 2 bevat een overzicht van de belangrijkste concurrenten van de onderscheiden opleidingen in het $\mathrm{KMBO}$ en $\mathrm{MBO}$. Hierin laten zich een viertal groepen van opleidingen onderscheiden. De eerste groep wordt gevormd door de opleidingen KMBO detailhandel, MDGO mode en kleding en de MMO detailhandelschool. Elk van deze opleidingen wordt op de arbeidsmarkt geconfronteerd met een

$0.04,0.05$ < gemiddeld $\leq 0.10,0.11<$ hoog $\leq 0.20$, erg hoog: $>0.21$. In de tabel zijn de categorieën erg laag en laag samengevoegd, evenals de categorieën erg hoog en hoog. 
zeer groot aantal (25!) concurrerende opleidingen voornamelijk afkomstig uit het VBO, het AVO, of andere opleidingen in het $(\mathrm{K}) \mathrm{MBO}$. De betreffende opleidingen beconcurreren elkaar met name in het beroepensegment van winkelpersoneel.

Een tweede groep die onderscheiden kan worden betreft de opleiding KMBO administratie en de verschillende opleidingen in het MEAO. Deze opleidingen concurreren vooral onderling en nauwelijks met andere opleidingen. De concurrentie vindt voornamelijk plaats in het segment van economisch-administratieve beroepen.

Een derde, betrekkelijk kleine groep betreft de opleidingen voor assistente gezondheidszorg. De schoolverlaters van deze drie opleidingen (doktersassistente, tandartsassistente, apothekersassistente) ontmoeten geen concurrenten op de arbeidsmarkt.

De opleidingen in de agrarische en technische sector, en een deel van de verzorgende opleidingen, kunnen tot de vierde groep gerekend worden. Dit betreffen opleidingen die op de arbeidsmarkt maar een beperkt aantal concurrenten tegenkomen. Deze concurrerende opleidingen betreffen in de regel een opleiding van een vergelijkbare richting, maar van een ander opleidingsniveau (bijvoorbeeld VBO of $\mathrm{HBO}$ ).

\subsection{De concurrentiestructuur op de arbeidsmarkt}

In deze paragraaf wordt een nadere analyse gemaakt van de concurrentiestructuur op de arbeidsmarkt. Vertrekpunt daarvoor is een clustering van opleidingen op basis van hun overeenkomst in beroependomein (zie hoofdstuk 3). Opleidingen die een vergelijkbaar beroependomein hebben vormen daarbij samen een cluster. De analyse wordt uitgevoerd op een bestand dat een dwarsdoorsnede vormt van de gediplomeerde uitstroom uit het gehele onderwijs, met uitzondering van het universitair onderwijs. In bijlage 3 wordt een overzicht gegeven van de clusters die deze analyse heeft opgeleverd. De analyse is gestart met 258 opleidingen. Deze zijn in de loop van het clusterproces teruggebracht tot 55 clusters van opleidingen. Daarnaast bleven 63 opleidingen over die niet met een andere opleiding geclusterd werden. Het clusterproces is beëindigd op het moment dat twee opleidingen zouden worden samengevoegd die inhoudelijk en op grond van de concurrentie-index te weinig overeenkomst in beroependomein hebben ${ }^{10}$.

Bij de clusteranalyse is gebruik gemaakt van alle in het bestand onderscheiden opleidingen. Opleidingen die met slechts een gering aantal cases in het bestand

10. Dit betrof de opleidingen MMO horeca en LTO grafische techniek. 
vertegenwoordigd zijn 'tellen' dus even zwaar mee als opleidingen die een groot aantal cases in het bestand hebben. De betrouwbaarheid waarmee het beroependomein van een 'kleine' opleiding kan worden vastgesteld is echter veel lager dan de betrouwbaarheid bij een grotere opleiding. Dit kan er toe leiden dat toevallige vertekeningen in het beroependomein van de kleinere opleidingen in het bestand het clusterproces sterk kunnnen verstoren. Voor alle opleidingen die minder dan 25 cases in het ongewogen bestand hebben, is daarom nagegaan of de eventuele clustering met andere opleidingen verdedigbaar is op grond van een overeenkomst in het opleidingsprofiel. Dat bleek vrijwel steeds het geval te zijn. In slechts elf van de 139 gevallen bleek een bijstelling noodzakeljk. De betreffende opleidingen zijn als 'niet te typeren' ingedeeld.

De robuustheid van de gevonden cluster oplossing is getest door dezelfde analyse nog eens uit te voeren, maar dan uitsluitend voor opleidingen met meer dan 25 cases in het bestand. Deze analyse resulteerde in vrijwel dezelfde concurrentiestructuur als in de eerste analyse. We concluderen derhalve dat de resultaten van de clusteranalyse voldoende robuust is.

Zoals aangegeven zijn in het clusterproces 55 clusters gevormd en resteerden 63 opleidingen die niet met een andere opleiding geclusterd werden. Deze 118 clusters en opleidingen kunnen onderscheiden worden in vijf categorieën. De eerste categorie bevat opleidingen die op de arbeidsmarkt een min of meer exclusief beroependomein hebben. Dit is geoperationaliseerd door binnen de groep opleidingen die niet geclusterd is met andere opleidingen te kijken naar de ondervonden concurrentie. Indien deze maatstaf als erg laag of laag is getypeerd, dan wordt relatief weinig concurrentie van andere opleidingen ondervonden en is het beroependomein van de opleiding min of meer exclusief. Deze opleidingen kunnen getypeerd worden als het professioneel segment.

De gevormde clusters kunnen vervolgens getypeerd worden naar de mate waarin de opleidingen die tot dat cluster behoren overeenkomsten vertonen wat betreft opleidngsniveau en opleidingsrichting. Om te beginnen kunnen clusters onderscheiden worden die homogeen zijn qua opleidingsrichting. In de regel zal dit een opleiding op een ander niveau betreffen, maar dat hoeft niet. Het gaat hier dus om opleidingen die een verwant beroependomein delen op grond van de specifieke richting. De desbetreffende opleidingen opereren op een deel van de arbeidsmarkt waar vakspecifieke kwalificaties van doorslaggevend belang zijn voor het selectieen allocatieproces. Deze vakspecifieke kwalificaties kunnen op verschillende niveaus in het onderwijs verworven worden. De richting van de verworven kwalificaties is echter van doorslaggevender belang in het allocatieproces dan het niveau waarop de kwalificatie verworven is. Deze clusters kunnen omschreven worden als het vakspecifiek segment. 
Vervolgens kunnen clusters onderscheiden worden, waarvan de opleidingen die tot dat cluster behoren weliswaar variatie vertonen naar opleidingsrichting, maar wel homogeen zijn naar opleidingsniveau. Deze opleidingen richten zich op dat deel van de arbeidsmarkt waar meer generieke kwalificaties vereist worden. Niet zozeer de specifieke opleiding die iemand gevolgd heeft is hier van belang, maar het feit dat iemand een opleiding op een bepaald niveau heeft afgesloten. De gevolgde opleiding geeft dan bijvoorbeeld een indicatie van het leervermogen waarover iemand beschikt of de aanwezigheid van andere generieke kwalificaties waarop door opleidingen geselecteerd wordt. Deze clusters kunnen omschreven worden als het generieke segment. Verwacht mag worden dat deze clusters zich vooral op de hogere opleidingsniveaus bevinden.

Ten slotte kunnen clusters onderscheiden worden waarbij de tot het cluster behorende opleidingen zowel naar niveau als naar richting variëren. Het betreft hier opleidingen die een deel van de arbeidsmarkt bestrijken waar geen strikte eisen aan de gevolgde opleiding worden gesteld (het niet-specifieke segment). Voor zover er al eisen worden gesteld zijn deze erg diffuus. Het gaat in de regel om opleidingen met een breed beroependomein of om opleidingen die zich op de onderkant van de arbeidsmarkt richten.

Dan resteren nog een aantal opleidingen en clusters die niet onder te brengen zijn in één van de voornoemde vier categorieën. Deze opleidingen en clusters zijn ondergebracht in een restcategorie. Immers er is wel sprake van overlap in beroependomein met andere opleidingen, gelet op de hoeveelheid ondervonden concurrentie. Deze is immers gemiddeld of hoog (anders was de betreffende opleiding bij het professioneel segment ingedeeld). Deze concurrentie wordt echter niet van een bepaalde opleiding in het bijzonder ondervonden, aangezien deze verwantschap onvoldoende is geweest om tot clustering over te gaan. Deze opleidingen zijn in een veel mindere mate toegespitst op de voorbereiding voor bepaalde beroepen dan de eerste categorie. Hun beroependomein is meer algemeen van aard en vertoont hierdoor vaker overeenkomsten met het beroependomein van andere opleidingen.

Samenvattend worden de volgende typen onderscheiden:

1) opleidingen die geen noemenswaardige concurrentie van andere opleidingen ondervinden op de arbeidsmarkt (type 1: professioneel segment);

2) clusters waarvan de opleidingen elk tot dezelfde opleidingsrichting behoren (type 2: vakspecifiek segment);

3) clusters waarvan de opleidingen elk tot hetzelfde opleidingsniveau behoren, maar niet tot dezelfde opleidingsrichting (type 3: generiek segment);

4) clusters waarvan de opleidingen variëren naar zowel opleidingsniveau als opleidingsrichting (type 4: niet-specifiek segment); 
5) overige clusters of opleidingen (type 5: restcategorie).

Tabel 4.2

De opleidingen per segment ${ }^{11}$

\begin{tabular}{lrrrrr}
\hline Segment & $\begin{array}{r}\text { VBO } \\
\%\end{array}$ & $\begin{array}{r}\text { KMBO } \\
\%\end{array}$ & $\begin{array}{r}\text { MBO } \\
\%\end{array}$ & $\begin{array}{r}\text { HBO } \\
\%\end{array}$ & $\begin{array}{r}\text { Totaal } \\
\%\end{array}$ \\
\hline Professioneel & 8.8 & 0.0 & 10.5 & 29.8 & 19.1 \\
Vakspecifiek & 64.7 & 86.7 & 56.6 & 52.1 & 57.3 \\
Generiek & 0.0 & 0.0 & 0.0 & 13.2 & 6.5 \\
Niet-specifiek & 17.7 & 13.3 & 25.0 & 0.8 & 11.4 \\
Overig & 8.8 & 0.0 & 7.9 & 4.1 & 5.7 \\
Totaal (N=100\%) & 34 & 15 & 76 & 121 & 246 \\
\hline
\end{tabular}

Tabel 4.2 geeft een overzicht van de indeling van de opleidingen in deze vijf segmenten. Opleidingen die een exclusief beroependomein hebben (type 1), duiden op het bestaan van zeer specialistische, professionele segmenten op de arbeidsmarkt. De opleidingen in deze segmenten ondervinden vrijwel geen concurrentie van andere opleidingen. In dit segment bevinden zich vooral HBO- opleidingen ${ }^{12}$.

Het merendeel van de opleidingen, ongeacht het opleidingsniveau, bevindt zich in het vakspecifieke segment (type 2). Dit geldt voor elk van de onderscheiden opleidingsniveaus, variërend van $52 \%$ van de opleidingen in het $\mathrm{HBO}$ tot $87 \%$ van de opleidingen in het KMBO. Het vakspecifieke segment is het segment waarbij de opleidingsrichting doorslaggevend is geweest voor de overlap in beroependomein. Dit duidt er op dat een groot deel van de arbeidsmarkt voor schoolverlaters uit het $\mathrm{VBO},(\mathrm{K}) \mathrm{MBO}$ en $\mathrm{HBO}$ onderscheiden kan worden in deelmarkten waarbij het belang van vakinhoudelijke kwalificaties doorslaggevend is.

Clusters waarbij alleen het opleidingsniveau doorslaggevend is geweest (type 3) vinden we, zoals verwacht, uitsluitend terug bij het $\mathrm{HBO}^{13}$. We hebben hier te maken met arbeidsmarktsegmenten waarbij allocatie plaatsvindt op basis van het niveau van de verworven kwalificaties. Op dit deel van de markt lijken vakinhoudelijke, sterk aan een beroep gebonden, kwalificaties van minder belang te zijn dan

11. De volgende opleidingen zijn buiten beschouwing gebleven: AVMB, VBO GGA, KMBO oriëntatie/schakel, VHBO en de AVO-opleidingen.

12. Het kan zijn dat de resultaten enigszins vertekenend kunnen zijn omdat WO-opleidingen buiten de analyse zijn gebleven. Wellicht zou een deel van de HBO opleidingen in dat geval in type 2 ondergebracht zijn.

13. Het kan zijn dat deze clusters wel concurreren met WO-opleidingen. 
meer algemene kwalificaties. Het efficiënt leren van nieuwe kennis en vaardigheden, het vermogen tot aanpassing in nieuwe en steeds wisselende situaties, het relatief zelfstandig uitvoeren van taken zouden op deze markten van groter belang kunnen zijn dan de meer beroepsspecifieke kwalificaties.

In het niet-specifieke segment (type 4), bevinden zich vooral VBO en (K)MBO opleidingen. Het bestaan van deze clusters verwijst naar delen van de arbeidsmarkt waar geen specifieke opleidingsvereisten gelden en waar de afbakening in beroependomein tussen de verschillende opleidingen erg diffuus is. Het gaat hier, zoals ook in de vorige paragraaf al is aangegeven, in feite om twee grote arbeidssegmenten (zie bijlage 3). Het ene segment wordt gevormd door het verkooppersoneel. Opleidingen die op dit segment opereren betreffen opleidingen uit het LEAO, LHNO, AVO, MMO en MDGO (Mode en Kleding). Het andere segment betreft de economisch-administratieve beroepen waarin alle opleidingen uit het MEAO zitten plus de opleiding KMBO Administratie ${ }^{14}$. Hoewel bij dit laatste segment sprake lijkt te zijn van meer homogeniteit en specifieke opleidingsvereisten, zijn de afbakeningen in de beroependomeinen van de verschillende opleidingen blijkbaar erg diffuus, waardoor ze in één segment geplaatst worden.

Tabel 4.3

Aantal opleidingen in professioneel segment naar niveau en sector

\begin{tabular}{lcccc}
\hline Sector & VBO & KMBO & MBO & HBO \\
\hline Agrarisch & 0 & 0 & 0 & 6 \\
Technisch & 2 & 0 & 2 & 7 \\
Verzorgend & 0 & 0 & 6 & 5 \\
Economisch & 1 & 0 & 0 & 4 \\
Kunsten & - & - & - & 6 \\
Agogisch & - & - & - & 5 \\
Onderwijs & - & - & - & 3 \\
\hline
\end{tabular}

In de tabellen 4.3 tot en met 4.6 is de typering van opleidingen verder uitgesplitst naar sector. Tabel 4.3 omvat de opleidingen die behoren tot de professionele deelmarkten (type 1). Bij het HBO kunnen in elk van de onderscheiden sectoren opleidingen van dit type worden teruggevonden. Dit betekent dat dergelijke professionele segmenten niet zozeer aan bepaalde sectoren gekoppeld zijn, maar veeleer aan een bepaald opleidingsniveau, in casu het HBO-niveau. Daarnaast

14. Ook de HBO opleiding Tolk/vertaler behoort tot dit segment, hoewel ze ook verwantschap vertoont met een cluster bestaande uit de commerciële en economisch-linguïstische opleidingen van het HEAO (zie bijlage 3 ). 
komen ook in de verzorgende sector van het MBO opleidingen voor die op een professioneel segment opereren.

In tabel 4.4 zijn de opleidingen weergegeven die als vakspecifiek zijn getypeerd (type 2). Hoewel in iedere sector deelmarkten voorkomen waar het belang van inhoudelijke, vakgerichte kwalificaties groot is, lijkt dit segment toch vooral voor te komen bij de agrarische en technische opleidingen in het VBO en (K)MBO. Voor de verzorgende opleidingen in het MBO geldt dat ze weliswaar het vaakst tot dit type behoren, maar ook relatief vaak tot type 1 of type 4 . In het HBO komt dit segment bij elk van de onderscheiden sectoren relatief vaak voor.

Tabel 4.4

Aantal opleidingen in vakspecifiek segment naar niveau en sector

\begin{tabular}{lrrrr}
\hline Sector & VBO & KMBO & MBO & HBO \\
\hline Agrarisch & 4 & 2 & 6 & 6 \\
Technisch & 15 & 8 & 20 & 16 \\
Verzorgend & 3 & 2 & 14 & 3 \\
Economisch & 0 & 1 & 3 & 14 \\
Kunsten & - & - & - & 16 \\
Agogisch & - & - & - & 3 \\
Onderwijs & - & - & - & 5 \\
\hline
\end{tabular}

In tabel 4.5 zijn de opleidingen gepresenteerd die lijken te opereren op markten waar vooral meer algemene kwalificaties op een bepaald niveau van doorslaggevende betekenis zijn. Zoals reeds aangegeven blijkt het hier uitsluitend om opleidingen op tenminste HBO niveau te gaan. Dit betekent dat de markt voor dit type kwalificaties beheerst wordt door HBO opleidingen (en waarschijnlijk ook de universitaire opleidingen). Dit segment lijkt zich met name voor te doen bij een aantal opleidingen uit de agrarische, de technische en de agogische sector en ontbreekt in sterk geprofessionaliseerde sectoren als verzorgend en onderwijs.

Tabel 4.5

Aantal opleidingen in generiek segment naar niveau en sector

\begin{tabular}{lllll}
\hline Sector & VBO & KMBO & MBO & HBO \\
\hline
\end{tabular}

\begin{tabular}{lcccc}
\hline & & & & \\
Agrarisch & 0 & 0 & 0 & 5 \\
Technisch & 0 & 0 & 0 & 4 \\
Verzorgend & 0 & 0 & 0 & 2 \\
Economisch & 0 & - & - & 1 \\
Kunsten & - & - & - & 4 \\
Agogisch & - & - & - & 0 \\
Onderwijs & - & & & \\
\hline
\end{tabular}


In tabel 4.6 zijn de niet-specifieke segmenten weergegeven. Het betreft hier sectoren waar geen specifieke opleidingsvereisten naar niveau en richting worden vereist. Zoals eerder aangegeven betreft het twee grote arbeidssegmenten, dat van het verkooppersoneeel en dat van de economisch-administratieve beroepen op lager en middelbaar niveau. Op dit segment komen uitsluitend opleidingen voor uit de verzorgende en economische sectoren op VBO en (K)MBO niveau.

Tabel 4.6

Aantal opleidingen in niet-specifiek segment naar niveau en sector

\begin{tabular}{lllll}
\hline Sector & VBO & KMBO & MBO & HBO \\
\hline
\end{tabular}

\begin{tabular}{lllrl} 
Agrarisch & 0 & 0 & 0 & 0 \\
Technisch & 0 & 0 & 0 & 0 \\
Verzorgend & 3 & 0 & 6 & 0 \\
Economisch & 3 & 2 & 13 & 1 \\
Kunsten & - & - & - & 0 \\
Agogisch & - & - & - & 0 \\
Onderwijs & - & - & - & 0 \\
\hline
\end{tabular}




\section{De afbakening van beroependomeinen van opleidingen in het middelbaar beroepsonderwijs}

\subsection{Inleiding}

In dit hoofdstuk zal een nadere analyse worden gegeven van de afbakening van beroependomeinen van de verschillende opleidingen in het middelbaar beroepsonderwijs (KMBO en $\mathrm{MBO}$ ). Zoals eerder aangegeven wordt daarbij gebruik gemaakt van de RUBS metingen uit de jaren 1992, 1993 en 1994. Door gebruik te maken van meerdere metingen kan een veel groter aantal opleidingen in het middelbaar beroepsonderwijs onderscheiden worden dan in het analysebestand dat voor hoofdstuk 4 is gebruikt. Het bestand omvat 21.000 schoolverlaters, afkomstig uit 187 verschillende opleidingen van het middelbaar beroepsonderwijs.

Met behulp van clusteranalyse is gekeken naar de overlap in beroependomeinen tussen deze opleidingen. Op grond hiervan worden 116 opleidingen samengevoegd tot 30 clusters. De overige 69 opleidingen bleken onvoldoende overlap te vertonen met andere opleidingen (of clusters van opleidingen) om tot clustering over te gaan. Een overzicht van de gevormde clusters wordt gepresenteerd in bijlage 4 . In de betreffende bijlage wordt bovendien voor elk van de onderscheiden opleidingen de beroepenspreiding en de ondervonden concurrentie weergegeven. De clusteranalyse levert voor de opleidingen in het middelbaar beroepsonderwijs vergelijkbare resultaten op als de analyse op het gekoppelde bestand van RUBS en HBO-Monitor dat is gebruikt in hoofdstuk 4. We concluderen derhalve dat de uitkomsten van de clusteranalyse zeer robuust zijn en dat de betreffende clustering een stabiele en betrouwbare weergave biedt van de overlap in beroependomeinen tussen de verschillende opleidingen.

In dit hoofdstuk zullen we nagaan welke opleidingen een eigen beroependomein hebben en welke opleidingen onderling overlap in beroependomein vertonen. Daarbij dient vooraf een aantal kanttekeningen te worden gemaakt.

Ten eerste heeft de analyse betrekking op de schoolverlaters uit het begin van de jaren ' 90 . Op dit moment is de opleidingsstructuur in het middelbaar beroepsonderwijs op een aantal punten al drastisch gewijzigd. Zo wordt nu een aantal tussenopleidingen onderscheiden, die in de oude opleidingsstructuur nog niet voorkwamen. Bovendien heeft in verschillende sectoren een herstructurering plaatsgevonden. Deze herstructurering is met name ingrijpend geweest voor de opleidingen in de agrarische sector. Om een indruk te geven van de huidige opleidingsstructuur is in bijlage 5 de indeling in opleidingen weergegeven die is opgenomen in de Studiegids MBO en Leerlingwezen 1996, welke door het Landelijk 
Dienstverlenend Centrum voor Studie- en Beroepskeuzevoorlichting wordt uitgegeven. Waar zinvol zullen we in onze bespreking van de uitkomsten van de clusteranalyse de resultaten steeds vergelijken met deze opleidingsstructuur ${ }^{15}$.

Ten tweede is een aantal kleinere opleidingen in het $(\mathrm{K}) \mathrm{MBO}$ in het verleden niet betrokken geweest bij het RUBS-onderzoek. Dit geldt met name voor een aantal nautische en agrarische opleidingen. Uiteraard kan dan ook geen uitspraak worden gedaan over de vraag of deze opleidingen een eigen beroependomein hebben.

Dat betekent dat we alleen een uitspraak kunnen doen welke 'oude' opleidingen in het middelbaar beroepsonderwijs overlap in beroependomein vertonen. Welke betekenis dat heeft voor de huidige opleidingen, hangt in belangrijke mate af van de mate waarin deze 'nieuwe' opleidingen met de 'oude' opleidingen corresponderen.

Wanneer twee opleidingen een sterke overlap in beroependomein vertonen, kan dit aanleiding zijn om zich te bezinnen op de vraag of deze opleidingen samengenomen zouden moeten worden tot één nieuwe opleiding. Dit is echter lang niet altijd wenselijk. Er kunnen zich minstens twee situaties voordoen waarbij het aanbeveling verdient om de afzonderlijke opleidingen te handhaven. De meest voorkomende situatie is dat opleidingen eenzelfde richting vertegenwoordigen, maar een verschillend niveau, namelijk als $\mathrm{KMBO}$ en $\mathrm{MBO}$ opleiding. Ondanks de verwantschap in beroependomein is het in zo'n geval wel degelijk zinvol om deze opleidingen in het middelbaar beroepsonderwijs op onderscheiden niveaus aan te bieden. Het feit dat schoolverlaters van een bepaalde KMBO opleiding in een zelfde beroepensegment zitten als de schoolverlaters van een vergelijkbare opleiding op MBO-niveau onderstreept alleen maar dat op de arbeidsmarkt blijkbaar behoefte bestaat aan beide typen opgeleiden. Wanneer zich deze situatie voordoet, is het derhalve zinvol om zowel een korte als een lange opleiding te onderscheiden. Juist wanneer een korte en een vergelijkbare lange opleiding niet in hetzelfde beroepensegment zitten, is het raadzaam om na te gaan of er wel behoefte bestaat aan beide opleidingsniveaus.

De andere situatie die zich voor kan doen is in zekere zin problematischer. Het kan voorkomen dat twee opleidingen een sterke overlap in het feitelijke beroependomein vertonen, maar dat wel beoogd wordt voor verschillende segmenten voor te bereiden. In zo'n geval zal de uitkomst van de clusteranalyse moeten leiden tot een nadere bezinning of integratie zinvol is en zo niet, op welke wijze het eigen profiel van een opleiding dan versterkt kan worden.

15. Overigens is ook de indeling in de betreffende studiegids binnenkort met het vaststellen van de nieuwe kwalificatiestructuur niet meer actueel. Richtinggevend is dan de opname van een kwalificatie in het CREBO. 
De werkwijze in dit hoofdstuk is als volgt. Per sector wordt een overzicht gepresenteerd van de opleidingen of clusters van opleidingen die op grond van de uitgevoerde analyses een eigen beroependomein hebben. Daarbij worden alle gevormde clusters, althans voor zover ze gebaseerd zijn op meer dan 25 waarnemingen, als opleidingscluster beschouwd met een eigen beroependomein. Voor de opleidingen die tot die clusters behoren verdient het derhalve aanbeveling om na te gaan of ze daadwerkelijk voor hetzelfde beroependomein voorbereiden en om die reden eventueel geïntegreerd zouden kunnen worden. Wanneer dat niet het geval is zou nagegaan moeten worden op welke wijze het eigen karakter van de opleiding dan versterkt kan worden. Indien in een cluster zowel een korte als een lange opleiding voorkomen, dan worden deze in de betreffende schema's apart onderscheiden. Bij de opleidingen die niet geclusterd zijn, is nagegaan hoe hoog de ondervonden concurrentie is. Indien deze maatstaf laag is of gemiddeld, dan heeft de betreffende opleiding blijkbaar een voldoende eigen beroependomein en worden ze apart in het schema vermeld. Ook hier geldt als grens dat de betreffende opleiding minimaal 25 waarnemingen in het bestand moet hebben.

In het gebruikte analysebestand kunnen in totaal 187 opleidingen onderscheiden worden in het middelbaar beroepsonderwijs. Op grond van de bovengenoemde werkwijze is dit ingedikt tot 53 opleidingen of clusters van opleidingen. Van deze opleidingen of clusters van opleidingen kan aangegeven worden dat ze een min of meer eigen beroependomein hebben. Er resteerden 56 opleidingen die een onvoldoende eigen beroependomein hebben om afzonderlijk onderscheiden te worden.

\subsection{De sector landbouw}

In de sector landbouw is de opleidingsstructuur in de afgelopen jaren drastisch gewijzigd. Zoals in bijlage 5 is aangegeven is nu sprake van 8 opleidingen (bij lang MBO 9) die elk als korte, tussen en lange opleiding worden aangeboden. Deze structuur is slechts zeer gedeeltelijk te herkennen bij de oude opleidingen, deels omdat de opleidingen qua curriculum veranderd zijn, deels omdat bepaalde opleidingen nieuw zijn. Dat geldt in ieder geval voor de tussenopleidingen die in de oude opleidingsstructuur nog niet voorkwamen. Vandaar dat in de hier gepresenteerde schema's de tussenopleidingen ook ontbreken.

Op grond van de resultaten van de clusteranalyse zouden de 'oude' opleidingen het best gegroepeerd kunnen worden in drie opleidingsclusters die elk een eigen beroependomein hebben: 'landbouw', 'tuinbouw' en 'tuinaanleg en -onderhoud' (zie schema 5.1). Binnen elk van deze clusters kan een korte en een lange opleiding onderscheiden worden. 
Schema 5.1

Clusters van opleidingen met eigen beroependomein in de sector landbouw

\begin{tabular}{ll}
\hline kort & lang \\
landbouw & landbouw \\
tuinbouw & tuinbouw \\
tuinaanleg en -onderhoud & tuinaanleg en -onderhoud \\
\hline
\end{tabular}

Door de verandering in de opleidingsstructuur valt niet aan te geven of de huidige indeling in 8 opleidingen voldoende gebaseerd is op herkenbare onderscheiden beroependomeinen. Op grond van de analyses kan wel als aandachtspunt worden geformuleerd of de opleiding levensmiddelentechnologie een voldoende herkenbaar eigen domein heeft. In ieder geval geldt voor de 'oude' MAS-A levensmiddelentechnologie, dat de schoolverlaters van deze opleiding een hoge concurrentie ondervinden van andere opleidingen (met name van de chemisch laboratorium opleiding), terwijl de 'oude' opleiding MAS-B levensmiddelen-technologie in één cluster samenvalt met MTO-procestechniek. Hierbij moet overigens aangetekend worden dat de clusteranalyse heeft plaatsgevonden op basis van overlap in de beroepen die schoolverlaters uitoefenen en niet op de bedrijfssector waar deze beroepen worden uitgeoefend. Kenmerkend voor de agrarische opleidingen is nu echter dat ze zich met deze opleidingen vaak op andere sectoren richt dan de technische opleidingen.

\subsection{De sector techniek}

De sector techniek is met 86 onderscheiden opleidingen de meest gedifferentieerde sector die in het bestand is opgenomen. Op grond van de uitgevoerde analyse kunnen 24 opleidingen of clusters van opleidingen onderscheiden worden. Van deze 24 opleidingen kan aangegeven worden dat ze een herkenbaar beroependomein hebben op de arbeidsmarkt. Daarnaast is nog een drietal opleidingen op inhoudelijke gronden onderscheiden ${ }^{16}$.

In schema 5.2 wordt een overzicht gegeven van deze opleidingen of clusters van opleidingen. De meeste van deze opleidingen kunnen ook als min of meer herkenbare opleiding in de huidige opleidingsstructuur worden aangetroffen. Ook hier geldt weer dat bepaalde opleidingen in het RUBS-bestand ontbreken (of nog niet bestonden) en zodoende niet als aparte opleiding naar voren zijn gekomen.

16. De lange opleiding installatietechniek is apart onderscheiden, omdat ook een korte opleiding installatietechniek is onderscheiden. Voor de lange opleidingen grafische techniek en nautische opleidingen, zie hoofdtekst. 
Schema 5.2

Clusters van opleidingen met eigen beroependomein in de sector techniek

\begin{tabular}{ll}
\hline kort & lang \\
bouw- en houtbewerking & bouwkunde \\
meubelmaken/meubelfabricage & meubelmaken/meubelfabricage \\
elektrotechniek & elektrotechniek \\
installatietechniek & installatietechniek \\
metaal & werktuigbouwkunde \\
motorvoertuigentechniek & motorvoertuigentechniek \\
procestechniek & procestechniek \\
brood- en banketbakken & brood- en banketbakken \\
grafische techniek & grafische techniek \\
& (reproduktietechnieken) \\
& weg- en waterbouwkunde \\
& edelsmeden \\
& wegenbouw \\
& optiek \\
biologisch laboratorium \\
chemisch laboratorium \\
medisch laboratorium \\
nautische opleidingen
\end{tabular}

Bij de sector techniek lijkt sprake te zijn van een zekere onevenwichtigheid in de huidige opleidingsstructuur (zie ook bijlage 5). Enerzijds zijn er afdelingen binnen de sector techniek die een bijzonder gedifferentieerde opleidingsstructuur hebben. Dit geldt met name voor de opleidingen in de grafische techniek en de nautische opleidingen. Anderzijds zijn er afdelingen die veel minder gedifferentieerd zijn en waar nadere specialisatie plaatsvindt door het volgen van differentiaties binnen de opleiding.

Uit de analyse komt naar voren dat er verschillende opleidingen zijn die een herkenbaar profiel op de arbeidsmarkt hebben. Voorbeelden hiervan zijn werktuigbouwkunde, motorvoertuigentechniek, bouwkunde, elektrotechniek of de verschillende laboratoriumopleidingen. Meer specifiek kunnen de volgende aandachtspunten geformuleerd worden:

- De opleidingen meubelmaken en meubelfabricage blijken een sterke overlap in beroependomein te vertonen.

- De afdeling edelsmeden kent op dit moment 4 verschillende opleidingen. Deze 4 opleidingen blijken een sterke overlap in beroependomein te vertonen.

- Bij de laboratoriumopleidingen komen de medische, biologische en chemische laboratoriumopleidingen duidelijk naar voren als opleidingen met een eigen beroependomein, hetgeen spoort met de huidige indeling. De huidige opleiding laboratoriumtechniek kent in veel mindere mate een eigen profiel vanwege een grote overlap in beroependomein met de medische laboratoriumopleiding.

- De brood- en banketopleidingen worden op dit moment zowel bij de korte als de lange opleidingen als twee aparte opleidingen aangeboden, waarbij onderscheid 
wordt gemaakt tussen het ambachtelijke bedrijf enerzijds en het industriële bakkersbedrijf anderzijds. Aangezien de analyse is uitgevoerd op het beroep dat uitgeoefend wordt en niet het bedrijf waar men werkzaam is, kan op grond van deze analyse niet worden aangegeven of een dergelijk onderscheid zinvol is.

- Bij de grafische opleidingen zijn de aantallen in het onderzoek betrokken waarnemingen te gering om harde uitspraken te kunnen doen over de overlap in beroependomein. In ieder geval kan worden vastgesteld dat de verschillende grafische opleidingen niet samen clusteren in één homogeen opleidingscluster. De enige opleiding die naar voren komt als opleiding met een eigen beroependomein betreft de opleiding reproduktietechnieken.

- Bij de nautische opleidingen geldt, net als bij de grafische opleidingen, dat het aantal in het onderzoek betrokken waarnemingen te gering is om betrouwbare uitspraken te doen. In ieder geval kan vastgesteld worden dat de verschillende oude opleidingen niet één homogeen cluster opleveren.

\subsection{De sector economie}

In de sector economie zijn drie opleidingen of clusters van opleidingen te onderscheiden die een duidelijk eigen beroepensegment hebben (zie schema 5.3). Dat betreft de lange opleiding 'toeristisch en recreatief onderwijs' en de korte en lange opleidingen 'horeca'. De lange opleiding horeca omvat tevens de opleiding consumptief-technische diensten van het MDGO.

Schema 5.3

Clusters van opleidingen met eigen beroependomein in de sector economie

\begin{tabular}{ll}
\hline kort & lang \\
$\begin{array}{ll}\text { administratie } \\
\text { detailhandel }\end{array}$ & $\begin{array}{l}\text { administratie (secretariaat) } \\
\text { detailhandel } \\
\text { horeca }\end{array}$ \\
& horeca \\
& toerisme en recreatie \\
\hline
\end{tabular}

Voor de afdeling administratie geldt dat de verschillende daaronder ressorterende opleidingen onderling een grote overlap in beroependomein vertonen, met uitzondering van de lange opleiding secretariaat. Deze overlap in beroependomein heeft vooral betrekking op het beroep van administratief medewerker. Bij de korte opleidingen kan, overeenkomstig de huidige opleidingsstructuur, duidelijk één opleiding administratie onderscheiden worden. Bij de lange opleidingen zou het aanbeveling verdienen om zich te bezinnen op het aantal onderscheiden opleidingen (bedrijfsadministratie, secretariaat, economisch-juridisch, commerciële dienstverlening, logistiek) vanwege de onderlinge overlap in beroependomeinen. 
De opleidingen detailhandel hebben betrekking op het beroepensegment van winkelpersoneel. Uit de eerder uitgevoerde analyses blijkt dat dit beroepensegment recruteert uit een zeer groot aantal opleidingen, niet alleen de hierop gerichte KMBO en MBO opleidingen, maar ook een groot deel van de opleidingen uit de MDGO afdeling mode en kleding en uiterlijke verzorging. Uit ander onderzoek dat door het ROA is uitgevoerd, blijkt dat in 1995 respectievelijk $80 \%$ en $76 \%$ van de schoolverlaters van de opleidingen (detail)handel in het KMBO en MBO niet werkzaam was in een baan waarvoor de eigen opleidingsrichting werd vereist (Van Smoorenburg en Willems, 1996). Bovendien was respectievelijk $70 \%$ en $43 \%$ van de betreffende schoolverlaters werkzaam in een functie onder het eigen opleidingsniveau. Het lijkt er derhalve op dat de betreffende opleidingen er slechts zeer gedeeltelijk in slagen om een eigen beroependomein te creëren op het niveau van beroepsbeoefenaar of vakfunctionaris.

\subsection{De sector dienstverlening en gezondheidszorg}

In de sector dienstverlening en gezondheidszorg kunnen op grond van de uitgevoerde clusteranalyse 12 (clusters van) opleidingen worden onderscheiden die een eigen beroependomein hebben (zie schema 5.4). Het is opvallend dat in deze sector vrij weinig overlap tussen opleidingen bestaat en dat de uit de clusteranalyse resulterende opleidingsstructuur redelijk overeenkomt met de huidige indeling in opleidingen. Dit is een duidelijke aanwijzing dat deze sector een redelijk transparante kwalificatiestructuur kent.

Schema 5.4

Clusters van opleidingen met eigen beroependomein in de sector dienstverlening en gezondheidszorg

\begin{tabular}{ll}
\hline kort & lang \\
verzorging & verzorging \\
uiterlijke verzorging & uiterlijke verzorging \\
& agogisch werk \\
& activiteitenbegeleiding \\
& sociale arbeid \\
& verpleging \\
& apothekersassistent \\
doktersassistent \\
tandartsassistent \\
sport en beweging \\
\end{tabular}

Extra aandacht in deze sector zou met name uit moeten gaan naar de afdeling mode en kleding. Uit de clusteranalyse blijkt dat de hieronder ressorterende opleidingen nauwelijks een eigen beroependomein kennen. Ult een ander onderzoek van het ROA blijkt dat de meeste afgestudeerden van deze opleidingen niet werkzaam zijn in de confectie, maar als winkelpersoneel. Van Smoorenburg en 
Willems (1996) geven aan dat $56 \%$ van de schoolverlaters van deze afdeling werkzaam is in de lagere verkoopberoepen. Mogelijkerwijs is een deel hiervan wel werkzaam in kledingzaken, maar dat valt op grond van de gegevens niet te onderscheiden. Wel blijkt dat ruim twee derde in een baan werkt waar geen specifieke opleidingsrichting werd vereist.

Voor de opleiding consumptief-technische diensten geldt dat deze zeer grote overlap vertoont met de horeca opleidingen binnen de sector economie. De opleiding civiele diensten blijkt eveneens een onvoldoende eigen beroependomein te hebben om als aparte opleiding onderscheiden te worden.

De 'oude' opleiding agogisch werk, met differentiaties naar cultureel werk en (semi-) residentieel blijkt één homogeen beroepensegment te vormen. Het verdient daarom aanbeveling om na te gaan of het huidige onderscheid in aparte opleidingen voor sociaal-pedagogisch werk en sociaal-cultureel werk zinvol is.

Binnen de 'oude' afdeling sociale arbeid komt de opleiding sociale dienstverlening naar voren als een opleiding met een duidelijk eigen beroependomein. Dit geldt echter niet voor de opleiding arbeidszaken en personeelswerk vanwege de hoge concurrentie met andere opleidingen.

Bij de afdeling uiterlijke verzorging komt de opleiding haarverzorging naar voren als een opleiding met een eigen beroependomein. Dat geldt echter niet voor de opleidingen voetverzorging en schoonheidsverzorging. Hier speelt hetzelfde probleem als bij de mode en kleding afdeling. De meeste schoolverlaters zijn werkzaam als winkelpersoneel en waarschijnlijk niet in het beroep waarvoor ze eigenlijk zijn opgeleid. Een mogelijke uitzondering betreffen schoolverlaters die bijvoorbeeld op een parfumerie-afdeling werken. Op grond van onze gegevens is echter niet te achterhalen welk percentage dit betreft.

De lange opleiding verzorging tenslotte ondervindt op de arbeidsmarkt voornamelijk concurrentie van de korte opleiding verzorging. De schoolverlaters van deze opleidingen komen met name terecht in beroepen in de gezins- en bejaardenverzorging of in de in-service opleidingen (Van Smoorenburg en Van der Velden, 1994). Gelet op dit specifieke beroependomein zijn beide opleidingen in het schema als afzonderlijke opleidingen onderscheiden. 


\section{Samenvatting}

In het kader van de ontwikkeling naar een landelijke kwalificatiestructuur voor het secundair beroepsonderwijs, zal een herijking plaatsvinden van de bestaande opleidingen. De doelstelling hiervan is om ondoelmatige overlap te voorkomen en een heldere transparante opleidingsstructuur te realiseren.

De Landelijke Organen Beroepsonderwijs spelen bij deze herijking een belangrijke rol. Om de discussie hierover goed te kunnen voeren is het van belang om over feitelijke informatie te beschikken omtrent de overlap in beroependomeinen van de opleidingen in het middelbaar beroepsonderwijs. Een dergelijke analyse van het feitelijke beroependomein van een opleiding en de eventuele overlap met andere opleidingen kan mede een basis vormen voor een inhoudelijke discussie over gewenste kwalificaties en eindtermen. Tegen deze achtergrond heeft het Instituut voor Onderzoek van het Onderwijs (SVO) in het najaar van 1995 aan het Researchcentrum voor Onderwijs en Arbeidsmarkt (ROA) opdracht verleend een verkennend onderzoek te verrichten op basis van bij het ROA beschikbare schoolverlatersgegevens.

Het ROA voert een tweetal grootschalige schoolverlatersonderzoeken uit die in dit kader van belang zijn. Het RUBS onderzoek (Registratie van Uitstroom en Bestemming van Schoolverlaters) heeft betrekking op schoolverlaters van de eerste en tweede fase van het voortgezet onderwijs. De HBO-Monitor heeft betrekking op de afgestudeerden van het hoger beroepsonderwijs. De opleidingen in het kader van het leerlingwezen en in-service onderwijs ontbreken vooralsnog in de schoolverlatersonderzoeken. Dit impliceert dat de uitgevoerde analyse uitsluitend betrekking heeft op de voltijd opleidingen in het secundair beroepsonderwijs.

De analyse in dit onderzoeksrapport spitst zich toe op een tweetal vraagstellingen. Enerzijds is nagegaan wat de positie is van de opleidingen in het KMBO en MBO ten opzichte van de andere opleidingen, met name de opleidingen in het VBO en $\mathrm{HBO}$. Hierbij is gekeken naar de belangrijkste concurrenten van deze opleidingen en naar de concurentiestructuur op de arbeidsmarkt voor schoolverlaters. Anderzijds is nagegaan wat de overlap is in beroependomein van de verschillende opleidingen in het middelbaar beroepsonderwijs.

De mate waarin opleidingen concurrentie ondervinden van andere opleidingen wordt bepaald door de overlap in het beroependomein. Opleidingen waarvan de afgestudeerden in dezelfde beroepen werkzaam zijn, kunnen op de arbeidsmarkt als elkaars concurrenten worden beschouwd. Met behulp van clusteranalyse is nagegaan welke opleidingen overlap vertonen wat betreft het beroependomein en 
welke opleidingen een geheel eigen beroependomein hebben. Het beroependomein van een opleiding wordt in dit rapport dus niet gebaseerd op inhoudelijke criteria, zoals de eindtermen van een opleiding of het beroepsopleidingsprofiel, maar op de feitelijke beroepen waarin de schoolverlaters van die opleiding terecht komen.

Bij de analyse van de concurrentiestructuur tussen opleidingen, zijn opleidingen onderscheiden in de volgende typen:

1) opleidingen die geen noemenswaardige concurrentie van andere opleidingen ondervinden op de arbeidsmarkt (type 1: professioneel segment);

2) opleidingen die concurrentie ondervinden van opleidingen die dezelfde opleidingsrichting aanbieden, maar in de regel op een ander opleidingsniveau (type 2: vakspecifiek segment);

3) opleidingen die concurrentie ondervinden van opleidingen die tot hetzelfde opleidingsniveau behoren, maar een geheel andere opleidingsrichting aanbieden (type 3: generiek segment);

4) opleidingen die concurrentie ondervinden van opleidingen die verschillen naar zowel opleidingsniveau als opleidingsrichting (type 4: niet-specifiek segment);

5) en een restcategorie waarin de overige opleidingen zijn ondergebracht (type 5 : restcategorie).

Ruim de helft van de opleidingen bevindt zich in het vakspecifieke segment (type 2). Dit geldt voor elk van de onderscheiden opleidingsniveaus, variërend van $52 \%$ van de opleidingen in het $\mathrm{HBO}$ tot $87 \%$ van de opleidingen in het KMBO. Dit is het segment waarbij de opleidingsrichting doorslaggevend is geweest voor de overlap in beroependomein. Dit duidt er op dat een groot deel van de arbeidsmarkt voor schoolverlaters uit het VBO, (K)MBO en HBO onderscheiden kan worden in deelmarkten waarbij het belang van vakinhoudelijke kwalificaties doorslaggevend is.

Opleidingen die behoren tot het professionele of generieke segment vinden we voornamelijk terug bij het HBO. In het niet-specifieke segment (type 4), bevinden zich vooral VBO en (K)MBO opleidingen. Deze clusters verwijzen naar delen van de arbeidsmarkt waar geen specifieke opleidingsvereisten gelden en waar de afbakening in beroependomein tussen de verschillende opleidingen erg diffuus is. Het gaat hier in feite om twee grote arbeidssegmenten. Het ene segment wordt gevormd door het verkooppersoneel. Opleidingen die op dit segment opereren betreffen opleidingen uit het LEAO, LHNO, AVO, MMO en MDGO (Mode en Kleding). Het andere segment betreft de economisch-administratieve beroepen waarin alle opleidingen uit het MEAO zitten plus de opleiding KMBO Administratie. Hoewel bij dit laatste segment sprake lijkt te zijn van meer homogeniteit en specifieke opleidingsvereisten, zijn de afbakeningen in de beroependomeinen van de verschillende opleidingen blijkbaar erg diffuus, waardoor ze in één segment terecht komen. 
Op basis van clusteranalyse is nagegaan welke opleidingen in het middelbaar beroepsonderwijs een eigen beroependomein hebben en welke opleidingen een sterke mate van overlap in beroependomein vertonen. Daarbij dient wel aangetekend te worden dat de analyse betrekking heeft op schoolverlaters die in het begin van de jaren ' 90 de opleiding verlaten hebben. Inmiddels is de opleidingsstructuur in sommige sectoren ingrijpend geherstructureerd. Dit geldt met name voor het landbouwonderwijs. Dit impliceert dat de nodige voorzichtigheid betracht moet worden bij de interpretatie van de gegevens. Daarbij geldt vanzelfsprekend dat specifieke uitkomsten met name betekenisvol zijn voor die sectoren in het (K)MBO die relatief weinig aan verandering onderhevig zijn geweest. Daarnaast heeft deze analyse een belangrijke betekenis omdat - voor het eerst - op een systematische wijze getracht is de feitelijke beroependomeinen van de verschillende opleidingen in het $(\mathrm{K}) \mathrm{MBO}$ in kaart te brengen en de onderlinge overlap vast te stellen. Ook voor opleidingen die inmiddels gewijzigd zijn levert dit belangrijke informatie op.

Wanneer twee opleidingen een sterke overlap in beroependomein vertonen, kan dit aanleiding zijn om zich te bezinnen op de vraag of deze opleidingen samengenomen zouden moeten worden tot één nieuwe opleiding. Dit is echter lang niet altijd wenselijk. Er kunnen zich minstens twee situaties voordoen waarbij het aanbeveling verdient om de afzonderlijke opleidingen te handhaven. De meest voorkomende situatie is dat opleidingen eenzelfde richting vertegenwoordigen, maar een verschillend niveau, namelijk als $\mathrm{KMBO}$ en $\mathrm{MBO}$ opleiding. Ondanks de verwantschap in beroependomein is het in zo'n geval wel degelijk zinvol om deze opleidingen in het middelbaar beroepsonderwijs op onderscheiden niveaus aan te bieden. Het feit dat schoolverlaters van een bepaalde KMBO opleiding in een zelfde beroepensegment zitten als de schoolverlaters van een vergelijkbare opleiding op MBO-niveau onderstreept alleen maar dat op de arbeidsmarkt blijkbaar behoefte bestaat aan beide typen opgeleiden. Wanneer zich deze situatie voordoet, is het derhalve zinvol om zowel een korte als een lange opleiding te onderscheiden. Juist wanneer een korte en een vergelijkbare lange opleiding niet in hetzelfde beroepensegment zitten, is het raadzaam om na te gaan of er wel behoefte bestaat aan beide opleidingsniveaus.

De andere situatie die zich voor kan doen is in zekere zin problematischer. Het kan voorkomen dat twee opleidingen een sterke overlap in het feitelijke beroependomein vertonen, maar dat wel beoogd wordt voor verschillende segmenten voor te bereiden. In zo'n geval zal de uitkomst van de clusteranalyse moeten leiden tot een nadere bezinning of integratie zinvol is en zo niet, op welke wijze het eigen profiel van een opleiding dan versterkt kan worden.

In de RUBS metingen van 1992, 1993 en 1994 kunnen in totaal 187 voltijd opleidingen in het middelbaar beroepsonderwijs onderscheiden worden. Op basis 
van de in dit onderzoek uitgevoerde analyse kan van 53 opleidingen of clusters van opleidingen aangegeven worden dat ze een eigen beroependomein hebben.

Voor de sector landbouw geldt dat de opleidingsstructuur inmiddels zodanig gewijzigd is dat hierover nauwelijks conclusies getrokken kunnen worden. Voor de sector techniek is de belangrijkste conclusie dat de 'oude' opleidingsstructuur soms erg gedifferentieerd was. Op grond van de uitgevoerde analyse kunnen in deze sector 27 (clusters van) opleidingen onderscheiden worden met een min of meer eigen beroependomein. Bij een groot aantal opleidingen binnen de sector techniek (zoals werktuigbouwkunde, of de laboratoriumopleidingen) is op dit moment reeds sprake van een herkenbaar 'eigen' beroependomein. Voor een aantal andere opleidingen geldt dat ze een sterke overlap in beroependomein vertonen met andere opleidingen. Bij deze opleidingen verdient het aanbeveling om na te gaan of integratie wenselijk is of dat juist het eigen karakter van de opleiding verder versterkt moet worden. Voor de grafische en nautische opleidingen geldt dat het aantal in het onderzoek betrokken waarnemingen te gering is om hierover betrouwbare uitspraken te doen.

Bij de sector economie verdienen met name de opleidingen die zich richten op de detailhandel nadere aandacht. Veel schoolverlaters van deze opleidingen komen terecht in banen waarvoor de eigen opleiding niet specifiek vereist is. Bovendien ontmoet men veel concurrentie van schoolverlaters uit andere opleidingen, met name van het VBO en AVO. Voor de opleidingen die behoren tot de afdeling administratie (bedrijfsadministratie, secretariaat, bestuurlijk etc.) geldt dat ze, met uitzondering van de opleiding secretariaat, een vrij grote mate van onderlinge overlap in beroependomein hebben. Het zou daarom aanbeveling kunnen verdienen om het eigen karakter van de betreffende opleidingen te versterken of om de opleidingen als differentiaties binnen één opleiding administratie aan te merken.

De sector dienstverlening en gezondheidszorg, tenslotte, lijkt op dit moment reeds een redelijk transparante kwalificatiestructuur te kennen. De uitgevoerde analyse levert voor deze sector een indeling op die vrijwel gelijk is aan de huidige opleidingsstructuur. De aandacht in deze sector zou met name uit moeten gaan naar de opleidingen mode en kleding en de opleidingen civiele diensten en consumptieftechnische diensten. Voor de opleidingen mode en kleding en de opleiding civiele diensten geldt dat de schoolverlaters van deze opleidingen in de afgelopen jaren niet een 'eigen' beroependomein op de arbeidsmarkt hebben verkregen. Dit zou aanleiding kunnen zijn om het eigen karakter van de opleiding verder te versterken. Bij de opleiding consumptieftechnische diensten geldt een sterke overlap in beroependomein met de horeca opleidingen uit de sector economie. 


\section{Literatuur}

Aldenderfer, M.S., R.K. Blashfield, Cluster Analysis, Sage University paper 44, Sage Publications, California, 1984.

Borghans, L., A Histo-Topographic Map of Dutch University Studies, ROA-W-1992/5E, Maastricht, 1992.

Borghans, L., R. van der Velden, M. Wiendels, De concurrentiepositie van opleidingen, ROA, Maastricht, nog te verschijnen.

Centraal Bureau voor de Statistiek, Beroepenclassificatie, 1985.

De Grip, A., L.F.M. Groot, J.A.M. Heijke, Clustering Occupational Classes by Educational Structure, ROA-W-1987/2E, Maastricht, 1987.

Loo, P.J.E. van de, R.K.W. van der Velden, De arbeidsmarktpositie van afgestudeerden van het hoger beroepsonderwijs, HBO-Monitor 1993, HBO-Raad, Den Haag, 1994.

Lorr, M., Cluster Analysis for Social Scientists, San Francisco, 1983.

Ministerie van Onderwijs, Cultuur en Wetenschappen, Format kwalificatiestructuur middelbaar beroepsonderwijs, Zoetermeer, 1994.

Smoorenburg, M.S.M. van, R.K.W. van der Velden, P.J.E. van de Loo. M.H. Wieling, Schoolverlaters op de arbeidsmarkt, De uitstroom en bestemming van het schooljaar 19911992, Stichting LDC, Leeuwarden, 1994.

Smoorenburg, M.S.M. van, R.K.W. van der Velden, Schoolverlaters op de arbeidsmarkt, De uitstroom en bestemming van het schooljaar 1992-1993, Stichting LDC, Leeuwarden, 1995a.

Smoorenburg, M.S.M. van, R.K.W. van der Velden, Schoolverlaters van het verzorgend onderwijs op de arbeidsmarkt. De uitstroom en bestemming van het schooljaar 1991-1992, Stichting LDC, Leeuwarden, 1995b.

Smoorenburg, M.S.M. van, E.J.T.A. Willems, Schoolverlaters tussen onderwijs en arbeidsmarkt 1995, ROA-R-1996/3, Maastricht, 1996.

SPSS Inc. SPSS Statistical Algorithms, 2nd Edition, Chicago, 1991.

Stichting Landelijk Dienstverlenend Centrum, Studiegids MBO en leerlingwezen '96, Leeuwarden, 1995.

Warnken, J., Zur Entwicklung der "Internen" Anpassungsfähigkeit der Berufe bis zum Jahre 2000. Projektionen unter den Annahmen der Wachstumzenarien der Prognos-Studie, in: Mitteilungen aus der Arbeitsmarkt- und Berufsforschung 1, pp. 119-133, 1986.

Wieling, M.H., A. de Grip, E.J.T.A. Willems, Een systematische kwalitatieve typering van arbeidsmarktinformatie, ROA-W-1990/8, Maastricht, 1990.

Wieling, M.H., P.J.E. van de Loo, R.K.W. van der Velden, Waar komen onze schoolverlaters terecht? De uitstroom en bestemming van het schooljaar 1990-1991, Stichting LDC, Leeuwarden, 1993. 



\section{Bijlage 1 Ondervonden concurrentie en beroepen- spreiding van opleidingen in het middelbaar beroepsonderwijs ${ }^{17}$}

\begin{tabular}{|c|c|c|c|}
\hline & $\begin{array}{l}\text { Aantal } \\
\text { cases }\end{array}$ & Concurrentie $^{18}$ & Beroepenspreiding $^{19}$ \\
\hline KMAO landbouw & 6 & - & - \\
\hline KMAO tuinbouw & 10 & - & - \\
\hline KMBO bouw- en houtbewerking & 19 & - & - \\
\hline $\begin{array}{l}\text { KMBO bouw- en houtbewerking: } \\
\text { schilderen }\end{array}$ & 1 & - & - \\
\hline KMBO Consumptieve techniek & 6 & - & - \\
\hline $\begin{array}{l}\text { KMBO Consumptieve techniek: } \\
\text { brood }\end{array}$ & 1 & - & - \\
\hline KMBO Electrotechniek & 43 & gemiddeld & gemiddeld \\
\hline KMBO Installatietechniek & 12 & - & - \\
\hline KMBO metaalbewerking & 24 & - & - \\
\hline KMBO motorvoertuigentechniek & 30 & laag & laag \\
\hline KMBO uiterlijke verzorging & 23 & - & - \\
\hline KMBO verzorgende beroepen & 121 & erg hoog & hoog \\
\hline KMBO detailhandel & 52 & erg hoog & gemiddeld \\
\hline KMBO administratie & 175 & hoog & hoog \\
\hline KMBO horeca & 14 & - & - \\
\hline KMBO oriëntatie/schakelen & 16 & - & - $\quad$ \\
\hline MAS-A: landbouw & 43 & gemiddeld & gemiddeld \\
\hline MAS-A: tuinbouw & 75 & gemiddeld & hoog \\
\hline MAS-A: levensmiddelen technologie & 20 & - & - \\
\hline MAS-B: landbouw & 40 & gemiddeld & gemiddeld \\
\hline MAS-B: tuinbouw & 75 & gemiddeld & hoog \\
\hline MAS-B: levensmiddelen technologie & 3 & - & - \\
\hline MTO bouwkunde & 116 & laag & hoog \\
\hline MTO electrotechniek & 196 & hoog & hoog \\
\hline MTO electrotechiek: & & & \\
\hline energietechniek & 10 & - & - \\
\hline MTS electrotechniek: & & & \\
\hline besturingstechniek & 5 & - & - \\
\hline MTO fijnmechanische techniek & 16 & - & - \\
\hline MTO motorvoertuigentechniek & 50 & gemiddeld & hoog \\
\hline MTO motorvoertuigentechniek: & & & \\
\hline $\begin{array}{l}\text { vervolgopleiding (VMVT) } \\
\text { MTO procestechniek }\end{array}$ & $\begin{array}{l}11 \\
14\end{array}$ & $\begin{array}{l}- \\
-\end{array}$ & $\begin{array}{l}- \\
-\end{array}$ \\
\hline MTO weg- en waterbouwkunde & 38 & laag & hoog \\
\hline MTO werktuigbouwkunde & 162 & gemiddeld & hoog \\
\hline $\begin{array}{l}\text { MTO werktuigbouwkunde: } \\
\text { besturingstechniek }\end{array}$ & 2 & - & - \\
\hline
\end{tabular}

17. Bron: RUBS 93, HBO-Monitor 93.

18. Uitsluitend voor opleidingen met meer dan 25 cases in het bestand.

19. Uitsluitend voor opleidingen met meer dan 25 cases in het bestand. 


\begin{tabular}{|c|c|c|c|}
\hline & $\begin{array}{l}\text { Aantal } \\
\text { cases }\end{array}$ & Concurrentie & Beroepensp \\
\hline $\begin{array}{l}\text { MTO werktuigbouwkunde: } \\
\text { installatietechniek }\end{array}$ & 2 & - & - \\
\hline MTO Overig wegenbouw: & & & \\
\hline machinist & 10 & - & - \\
\hline $\begin{array}{l}\text { MTO Overig wegenbouw: } \\
\text { technicus }\end{array}$ & 8 & - & - \\
\hline MTO Overig wegenbouw: & & & \\
\hline monteur & 7 & - & - \\
\hline MLO/KMLO: biologisch & 5 & - & - \\
\hline MLO/KMLO: chemisch & 30 & laag & gemiddeld \\
\hline MLO/KMLO: laboratoriumtechniek & 2 & - & - \\
\hline MLO: biologisch & 6 & - & - \\
\hline MLO: chemisch & 61 & laag & gemiddeld \\
\hline MLO: laboratoriumtechniek & 2 & - & - \\
\hline MLO: medisch & 31 & erg laag & erg laag \\
\hline MNO visserijschool: & & & \\
\hline $\begin{array}{l}\text { opleiding SWV } \\
\text { MDGO verzorging VZ }\end{array}$ & $\begin{array}{r}2 \\
923\end{array}$ & gemiddeld & gemiddeld \\
\hline MDGO sociale arbeid SA & 19 & - & - \\
\hline $\begin{array}{l}\text { MDGO sociale arbeid: arbeidszaken/ } \\
\text { personeelswerving SA (SA/AP) }\end{array}$ & 20 & - & - \\
\hline $\begin{array}{l}\text { MDGO sociale arbeid: sociale } \\
\text { dienstverlening SA (SA/SD) }\end{array}$ & 18 & - & - \\
\hline MDGO agogisch werk AW & 128 & gemiddeld & gemiddeld \\
\hline $\begin{array}{l}\text { MDGO agogisch werk: } \\
\text { agogisch werk AW (AW) }\end{array}$ & 14 & 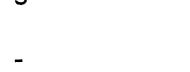 & (5) \\
\hline $\begin{array}{l}\text { MDGO agogisch werk: } \\
\text { (semi)-residentieel AW (AW/RW) }\end{array}$ & 323 & gemiddeld & gemiddeld \\
\hline $\begin{array}{l}\text { MDGO agogisch werk: } \\
\text { cultureel werk AW (AW/CW) }\end{array}$ & 21 & 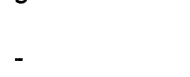 & 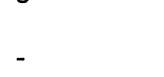 \\
\hline $\begin{array}{l}\text { MDGO assistenten } \\
\text { gezondheidszorg AG }\end{array}$ & 94 & laag & gemiddeld \\
\hline $\begin{array}{l}\text { MDGO assistenten gezondheidszorg: } \\
\text { apothekersassistenten AG (AG/AA) }\end{array}$ & 197 & erg laag & erg laag \\
\hline $\begin{array}{l}\text { MDGO assistenten gezondheidszorg: } \\
\text { doktersassistenten AG (AG/DA) }\end{array}$ & 203 & laag & laag \\
\hline $\begin{array}{l}\text { MDGO assistenten gezondheidszorg: } \\
\text { tandartsassistenten } A G(A G / T A)\end{array}$ & 66 & erg laag & erg laag \\
\hline $\begin{array}{l}\text { MDGO civiel \& consumptief- } \\
\text { technische diensten CCD }\end{array}$ & 15 & - & - \\
\hline $\begin{array}{l}\text { MDGO civiel \& consumptief- } \\
\text { technische diensten: civiel \& } \\
\text { consumptieftechnische } \\
\text { diensten CCD (CCD) }\end{array}$ & 2 & - & - \\
\hline $\begin{array}{l}\text { MDGO civiel \& consumptief- } \\
\text { technische diensten: civiele } \\
\text { diensten CCD (CCD/CD) }\end{array}$ & 21 & - & - \\
\hline $\begin{array}{l}\text { MDGO civiel \& consumptief- } \\
\text { technische diensten: consumptief- } \\
\text { technische diensten CCD (CCD/CT) }\end{array}$ & 64 & gemiddeld & gemiddeld \\
\hline
\end{tabular}




\begin{tabular}{|c|c|c|c|}
\hline & $\begin{array}{l}\text { Aantal } \\
\text { cases }\end{array}$ & Concurrentie & Beroepenspreiding \\
\hline MDGO mode \& kleding MK & 77 & erg hoog & gemiddeld \\
\hline $\begin{array}{l}\text { MDGO mode \& kleding: } \\
\text { realisatie MK (MK/R) }\end{array}$ & 114 & erg hoog & gemiddeld \\
\hline $\begin{array}{l}\text { MDGO mode \& kleding: } \\
\text { commercieel MK (MK/C) }\end{array}$ & 45 & erg hoog & gemiddeld \\
\hline $\begin{array}{l}\text { MDGO mode \& kleding: } \\
\text { presentatie MK (MK/P) }\end{array}$ & 99 & erg hoog & gemiddeld \\
\hline MDGO activiteitenbegeleiding $A B$ & 156 & laag & laag \\
\hline MDGO sport \& beweging SB & 97 & laag & laag \\
\hline $\begin{array}{l}\text { MDGO uiterlijke verzorging UV } \\
\text { MDGO uiterlijke verzorging: }\end{array}$ & 34 & gemiddeld & gemiddeld \\
\hline haarverzorging UV (UV/HV) & 34 & gemiddeld & erg laag \\
\hline $\begin{array}{l}\text { MDGO uiterlijke verzorging: } \\
\text { vakbekwaamheid dames- en } \\
\text { herenkappen UV (UVNDH) }\end{array}$ & 18 & - & - \\
\hline $\begin{array}{l}\text { MDGO uiterlijke verzorging: } \\
\text { schoonheids- en voet- }\end{array}$ & & & \\
\hline $\begin{array}{l}\text { verzorging UV UVISV-VV } \\
\text { MDGO uiterlijke verzorging: } \\
\text { ondernemer schoonheids- en } \\
\text { voetverzorging UV (UV/OSV) }\end{array}$ & 13 & - & - \\
\hline $\begin{array}{l}\text { MDGO uiterlijke verzorging: } \\
\text { ondernemer schoonheids- } \\
\text { verzorging UV (UV/OS) }\end{array}$ & 2 & - & - \\
\hline MDGO verpleging VP & 127 & gemiddeld & gemiddeld \\
\hline INTAS & 1 & - & - \\
\hline INTAS 1-jarig & 7 & - & - \\
\hline VHBO & 36 & erg hoog & hoog \\
\hline MEAO bedrijfsadministratief & 355 & hoog & hoog \\
\hline MEAO commercieel & 167 & hoog & hoog \\
\hline MEAO bestuurlijk & 26 & hoog & hoog \\
\hline MEAO secretariaats & 351 & hoog & hoog \\
\hline MEAO vrije richting & 89 & erg hoog & hoog \\
\hline MEAO logistiek & 22 & - & - \\
\hline MEAO directie-secretariaat & 9 & - & - \\
\hline MEAO commercieel/secretariaats & 6 & - & - \\
\hline MEAO bank- en verzekeringswezen & 8 & - & - \\
\hline MMO detailhandelschool & 17 & - & - \\
\hline MMO detailhandelschool: & & & \\
\hline MMO-BD branchedifferentiatie & 213 & erg hoog & hoog \\
\hline MMO detailhandelschool: MMO-C & 217 & erg hoog & hoog \\
\hline $\begin{array}{l}\text { MMO detailhandelschool: } \\
\text { MMO-G groothandel }\end{array}$ & 22 & - & - \\
\hline MMO horecaschool MHS & 99 & hoog & hoog \\
\hline MMO toerisme & 29 & gemiddeld & gemiddeld \\
\hline MTRO & 13 & - & - \\
\hline MMO Bakkerij & 20 & - & - \\
\hline HAVO/MBO & 41 & hoog & hoog \\
\hline
\end{tabular}





\section{Bijlage 2 De belangrijkste concurrenten van de opleidingen in het middelbaar beroeps- onderwijs ${ }^{20}$}

\section{KMBO Electrotechniek}

LTO Electrotechniek $\quad 0.95$

$\begin{array}{ll}\text { MTO Electrotechniek } & 0.77\end{array}$

MTO Electrotechniek: energietechniek $\quad 0.74$

KMBO motorvoertuigentechniek

$\begin{array}{ll}\text { LTO Motorvoertuigentechniek } & 0.96\end{array}$

LTO Motorvoertuigentechniek: landbouwwerktuigen $\quad 0.62$

MTO motorvoertuigentechniek $\quad 0.89$

MTO motorvoertuigentechniek: vervolgopleiding (VMVT) 0.95

KMBO verzorgende beroepen

$\begin{array}{ll}\text { LHNO verzorgende beroepen } & 0.61\end{array}$

LEAO winkelpraktijk $\quad 0.50$

\begin{tabular}{ll} 
MDGO verzorging $V Z$ & 0.50 \\
\hline & 0.68
\end{tabular}

MAVO $\quad 0.56$

MAVO-4 $\quad 0.54$

KMBO detailhandel

LAO land- en tuinbouw: bloemsierkunst $\quad 0.50$

$\begin{array}{ll}\text { LHNO verzorgende beroepen } & 0.79\end{array}$

LHNO textielverwerkende beroepen $\quad 0.84$

LHNO uiterlijke verzorging $\quad 0.51$

LHNO kantoor/verkooppraktijk $\quad 0.96$

LMO $\quad 0.94$

LEAO kantoorpraktijk $\quad 0.81$

LEAO winkelpraktijk $\quad 0.93$

AVMB algemene vorming op maatschappij en beroep $\quad 0.90$

MTO fijnmechanische techniek $\quad 0.75$

MMO detailhandelschool: branchedifferentiatie MMO-BD 0.92

MMO detailhandelschool MMO-C $\quad 0.92$

$\begin{array}{ll}\text { MDGO civiel \& consumptieftechnische diensten } & 0.67\end{array}$

MDGO mode en kleding MK $\quad 0.94$

MDGO mode en kleding: realisatie MK (MK/R) $\quad 0.92$

MDGO mode en kleding: commercieel MK (MK/C)

$\begin{array}{ll}\text { MDGO mode en kleding: presentatie MK (MK/P) } & 0.91\end{array}$

MDGO uiterlijke verzorging: ondernemer schoonheids- en voetverzorging 0.80

MDGO uiterlijke verzorging: ondernemer schoonheidsverzorging UV (UV/OS) 0.67

MAVO

20. Uitsluitend voor opleidingen met meer dan 25 cases in het bestand. Belangrijkste concurrenten zijn opleidingen waarbij de concurrentie-index groter is dan 0.50 (Bron: RUBS 93, HBO-Monitor 93). 
MAVO-4

HAVO

WWO

0.75

Vormgeving metalen en kunststoffen

Opl praktijkdiploma directie, harmonie en fanfare

\section{KMBO administratie}

$\begin{array}{lr}\text { LEAO kantoorpraktijk } & 0.55 \\ \text { MMO detailhandelschool } & 0.74 \\ \text { MEAO bedrijfsadministratief } & 0.81 \\ \text { MEAO commercieel } & 0.82 \\ \text { MEAO bestuurlijk } & 0.74 \\ \text { MEAO secretariaats } & 0.79 \\ \text { MEAO vrije richting } & 0.86 \\ \text { MDGO sociale arbeid: sociale dienstverlening SA (SA/SD) } & 0.53 \\ \text { VHBO } & 0.55\end{array}$

MAS-A landbouw

$\angle A O$ land- en tuinbouw

$L A O$ land- en tuinbouw: dierenhouderij

KMAO landbouw

MAS-B landbouw

0.91

HAS bosbouw (bos \& natuurbeheer)

MAS-A tuinbouw

LAO land- en tuinbouw

LAO land- en tuinbouw: bloemsierkunst

MAS-B tuinbouw

MAS-B landbouw

LAO land- en tuinbouw

$L A O$ land- en tuinbouw: dieren

KMAO landbouw

MAS-A landbouw

MAS-B tuinbouw

LAO land- en tuinbouw

LAO land- en tuinbouw: bloemsierkunst

MTO bouwkunde

MTO weg- en waterbouwkunde $\quad 0.58$

HTO Bouwkunde

\section{MTO electrotechniek}

LTO Electrotechniek

KMBO Electrotechniek 
MTO motorvoertuigentechniek

$\begin{array}{ll}\text { LTO Motorvoertuigentechniek } & 0.87\end{array}$

LTO Motorvoertuigentechniek: landbouwwerktuigen $\quad 0.52$

$\begin{array}{ll}\text { KMBO motorvoertuigentechniek } & 0.89\end{array}$

$\begin{array}{ll}\text { MTO motorvoertuigentechniek (VMVT) } & 0.88\end{array}$

MTO weg- waterbouwkunde

MTO bouwkunde $\quad 0.58$

HTO Weg-en waterbouwkunde (CT) $\quad 0.50$

MTO werktuigbouwkunde

LTO Overige opleidingen: theoretisch/technisch TTO 0.54

$\begin{array}{ll}\text { HTO Werktuigbouwkunde } & 0.54\end{array}$

MLO/KMLO: chemisch

$\begin{array}{ll}\text { MLO: chemisch } & 0.87\end{array}$

$\begin{array}{ll}\text { MAS-A levensmiddelentechnologie } & 0.62\end{array}$

MLO: chemisch

$\begin{array}{ll}\text { MLO KMLO: chemisch } & 0.87\end{array}$

$\begin{array}{ll}\text { HLO Chemische laboratoriumopleiding } & 0.76\end{array}$

MLO: medisch

$\begin{array}{ll}\text { HLO Medische laboratoriumopleiding } & 0.94\end{array}$

MDGO verzorging VZ

$\begin{array}{ll}\mathrm{KMBO} \text { verzorgende beroepen } & 0.68\end{array}$

MDGO agogisch werk AW

MDGO agogisch werk: agogisch werk AW (AW) 0.92

MDGO agogisch werk: (semi)-residentieel AW (AW/RW) 0.98

MDGO agogisch werk: cultureel werk AW (AW/CW) 0.93

$\begin{array}{ll}\text { Opleiding getuigschrift muziekonderwijs A-(amv) } & 0.63\end{array}$

MDGO agogisch werk: (semi)-residentieel AW (AW/RW)

MDGO agogisch werk AW 0.98

$\begin{array}{ll}\text { MDGO agogisch werk: agogisch werk AW (AW) } & 0.94\end{array}$

MDGO agogisch werk: cultureel werk AW (AW/CW) 0.94

$\begin{array}{ll}\text { Opleiding getuigschrift muziekonderwijs A-(amv) } & 0.64\end{array}$

MDGO assistenten gezondheidszorg AG

MDGO assistenten gezondheidszorg: apothekersassistenten AG (AG/AA) $\quad 0.53$

MDGO assistenten gezondheidszorg: doktersassistenten AG (AG/DA) 0.77

MDGO assistenten gezondheidszorg: apothekersassistenten AG (AG/AA)

MDGO assistenten gezondheidszorg AG 
MDGO assistenten gezondheidszorg: doktersassistenten AG (AG/DA)

MDGO assistenten gezondheidszorg AG

MDGO assistenten gezondheidszorg: tandartsassistenten AG (AG/TA)

geen belangrijke concurrenten

MDGO civiel \& consumptieftechnische diensten: consumptieftechnische diensten (CCD/CT)

LTO Consumptieve techniek

0.89

LTO Consumptieve techniek: algemeen $\quad 0.79$

$\begin{array}{ll}\text { LTO Consumptieve techniek: koken } & 0.88\end{array}$

LHNO vrije studierichting $\quad 0.58$

$\begin{array}{ll}\text { KMBO horeca } & 0.98\end{array}$

$\begin{array}{ll}\text { MDGO civiel \& consumptieftechnische diensten } & 0.76\end{array}$

MDGO mode en kleding MK

LAO land- en tuinbouw: bloemsierkunst $\quad 0.55$

$\begin{array}{ll}\text { LHNO verzorgende beroepen } & 0.77\end{array}$

$\begin{array}{ll}\text { LHNO textielverwerkende beroepen } & 0.80\end{array}$

$\begin{array}{ll}\text { LHNO uiterlijke verzorging } & 0.53\end{array}$

$\begin{array}{ll}\text { LHNO kantoor/verkooppraktijk } & 0.96\end{array}$

$\begin{array}{ll}\text { LMO } & 0.87\end{array}$

$\begin{array}{ll}\text { LEAO kantoorpraktijk } & 0.85\end{array}$

LEAO winkelpraktijk $\quad 0.88$

AVMB algemene vorming op maatschappij en beroep $\quad 0.91$

$\begin{array}{ll}\text { KMBO detailhandel } & 0.94\end{array}$

$\begin{array}{ll}\text { MTO fijnmechanische techniek } & 0.75\end{array}$

MMO detailhandelschool: branchedifferentiatie MMO-BD 0.95

$\begin{array}{ll}\text { MMO detailhandelschool (MMO-C) } & 0.93\end{array}$

MDGO civiel \& consumptieftechnische diensten $\quad 0.68$

$\begin{array}{ll}\text { MDGO mode en kleding: realisatie MK (MK/R) } & 0.95\end{array}$

MDGO mode en kleding: commercieel MK (MK/C) $\quad 0.97$

$\begin{array}{ll}\text { MDGO mode en kleding: presentatie MK (MK/P) } & 0.95\end{array}$

MDGO uiterlijke verzorging: ondernemer schoonheids- en voetverzorging $\quad 0.80$

MDGO uiterlijke verzorging: ondernemer schoonheidsverzorging UV (UV/OS) 0.72

$\begin{array}{ll}\text { MAVO } & 0.72\end{array}$

$\begin{array}{ll}\text { MAVO-4 } & 0.80 \\ \text { MAVO } & 0.74\end{array}$

$\begin{array}{ll}\text { HAVO } & 0.74\end{array}$

$\begin{array}{ll}\text { WWO } & 0.79\end{array}$

Vormgeving metalen en kunststoffen $\quad 0.55$

Opleiding praktijkdiploma directie, harmonie en fanfare $\quad 0.68$

MDGO mode en kleding: realisatie MK (MK/R)

LAO land- en tuinbouw: bloemsierkunst $\quad 0.52$

$\begin{array}{ll}\text { LHNO verzorgende beroepen } & 0.76\end{array}$

LHNO textielverwerkende beroepen $\quad 0.80$

$\begin{array}{ll}\text { LHNO uiterlijke verzorging } & 0.52\end{array}$

LHNO kantoor/verkooppraktijk $\quad 0.94$ 
LMO

$\begin{array}{ll}\text { LEAO kantoorpraktijk } & 0.80\end{array}$

LEAO winkelpraktijk $\quad 0.86$

AVMB algemene vorming op maatschappij en beroep $\quad 0.90$

$\begin{array}{ll}\text { KMBO detailhandel } & 0.92\end{array}$

$\begin{array}{ll}\text { MTO fijnmechanische techniek } & 0.74\end{array}$

MMO detailhandelschool: branchedifferentiatie MMO-BD 0.93

$\begin{array}{ll}\text { MMO detailhandelschool (MMO-C) } & 0.92\end{array}$

MDGO civiel \& consumptieftechnische diensten $\quad 0.67$

MDGO mode en kleding MK $\quad 0.95$

MDGO mode en kleding: commercieel MK (MK/C) $\quad 0.95$

MDGO mode en kleding: presentatie MK (MK/P) 0.93

MDGO uiterlijke verzorging: ondernemer schoonheids- en voetverzorging $\quad 0.80$

MDGO uiterlijke verzorging: ondernemer schoonheidsverzorging UV (UV/OS) 0.67

$\begin{array}{ll}\text { MAVO } & 0.68\end{array}$

$\begin{array}{ll}\text { MAVO-4 } & 0.78\end{array}$

HAVO $\quad 0.70$

$\begin{array}{ll}\text { WWO } & 0.77\end{array}$

Vormgeving metalen en kunststoffen $\quad 0.55$

Opleiding praktijkdiploma directie, harmonie en fanfare $\quad 0.67$

MDGO mode en kleding: commercieel MK (MK/C)

LAO land- en tuinbouw: bloemsierkunst $\quad 0.53$

$\begin{array}{ll}\text { LHNO verzorgende beroepen } & 0.75\end{array}$

$\begin{array}{ll}\text { LHNO textielverwerkende beroepen } & 0.77\end{array}$

LHNO uiterlijke verzorging $\quad 0.53$

LHNO kantoor/verkooppraktijk $\quad 0.95$

$\begin{array}{ll}\text { LMO } & 0.87\end{array}$

$\begin{array}{ll}\text { LEAO kantoorpraktijk } & 0.81\end{array}$

LEAO winkelpraktijk $\quad 0.86$

AVMB algemene vorming op maatschappij en beroep $\quad 0.91$

$\begin{array}{ll}\text { KMBO detailhandel } & 0.93\end{array}$

$\begin{array}{ll}\text { MTO fijnmechanische techniek } & 0.75\end{array}$

MMO detailhandelschool: branchedifferentiatie MMO-BD 0.95

$\begin{array}{ll}\text { MMO detailhandelschool (MMO-C) } & 0.94\end{array}$

MDGO civiel \& consumptieftechnische diensten $\quad 0.68$

$\begin{array}{ll}\text { MDGO mode en kleding MK } & 0.97\end{array}$

MDGO mode en kleding: realisatie MK (MK/R) $\quad 0.95$

MDGO mode en kleding: presentatie MK (MK/P) $\quad 0.94$

MDGO uiterlijke verzorging: ondernemer schoonheids- en voetverzorging 0.81

MDGO uiterlijke verzorging: ondernemer schoonheidsverzorging UV (UV/OS) 0.68

$\begin{array}{ll}\text { MAVO } & 0.69\end{array}$

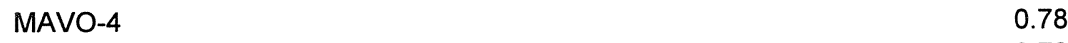

HAVO $\quad 0.72$

$\begin{array}{ll}\text { WWO } & 0.79\end{array}$

Vormgeving metalen en kunststoffen $\quad 0.56$

Opleiding praktijkdiploma directie, harmonie en fanfare $\quad 0.68$ 
MDGO mode en kleding: presentatie MK (MK/P)

LAO land- en tuinbouw: bloemsierkunst $\quad 0.69$

$\begin{array}{ll}\text { LHNO verzorgende beroepen } & 0.75\end{array}$

$\begin{array}{ll}\text { LHNO textielverwerkende beroepen } & 0.77\end{array}$

LHNO uiterlijke verzorging $\quad 0.53$

LHNO kantoor/verkooppraktijk $\quad 0.94$

LMO $\quad 0.86$

LEAO kantoorpraktijk $\quad 0.83$

$\begin{array}{ll}\text { LEAO winkelpraktijk } & 0.87\end{array}$

AVMB algemene vorming op maatschappij en beroep $\quad 0.90$

$\begin{array}{ll}\text { KMBO detailhandel } & 0.91\end{array}$

$\begin{array}{ll}\text { MTO fijnmechanische techniek } & 0.74\end{array}$

MMO detailhandelschool: branchedifferentiatie MMO-BD $\quad 0.94$

$\begin{array}{ll}\text { MMO detailhandelschool (MMO-C) } & 0.94\end{array}$

MDGO sociale arbeid SA $\quad 0.50$

MDGO civiel \& consumptieftechnische diensten $\quad 0.67$

MDGO mode en kleding MK $\quad 0.95$

MDGO mode en kleding: realisatie MK (MK/R) $\quad 0.93$

MDGO mode en kleding: commercieel MK (MK/C) $\quad 0.94$

MDGO uiterlijke verzorging: ondernemer schoonheids- en voetverzorging $\quad 0.80$

MDGO uiterlijke verzorging: ondernemer schoonheidsverzorging UV (UV/OS) 0.67

$\begin{array}{ll}\text { MAVO } & 0.69\end{array}$

$\begin{array}{ll}\text { MAVO-4 } & 0.78\end{array}$

$\begin{array}{ll}\text { HAVO } & 0.73\end{array}$

WWO $\quad 0.80$

Vormgeving metalen en kunststoffen $\quad 0.55$

$\begin{array}{ll}\text { Opleiding praktijkdiploma directie, harmonie en fanfare } & 0.67\end{array}$

MDGO activiteitenbegeleiding $A B$

MDGO civiel \& consumptieftechnische diensten $\quad 0.72$

MDGO sport en beweging SB

$\begin{array}{lr}\text { HPO 1e graads lichamelijke oefening } & 0.56\end{array}$

MDGO uiterlijke verzorging UV

LHNO textielverwerking \& verkoop $\quad 0.85$

LHNO uiterlijke verzorging $\quad 0.56$

LHNO vrije studierichting $\quad 0.57$

$\begin{array}{ll}\text { LHNO huishoudkunde } & 0.60\end{array}$

KMBO uiterlijke verzorging $\quad 0.67$

MDGO uiterlijke verzorging: haarverzorging UV (UV/HV) $\quad 0.86$

MDGO uiterlijke verzorging: vakbekwaamheid dames- en herenkappen $\quad 0.85$

MDGO uiterlijke verzorging: haarverzorging UV (UV/HV)

LHNO textielverwerking \& verkoop $\quad 0.99$

LHNO uiterlijke verzorging $\quad 0.59$

$\begin{array}{ll}\text { LHNO vrije studierichting } & 0.67\end{array}$

$\begin{array}{ll}\text { LHNO huishoudkunde } & 0.70\end{array}$

KMBO uiterlijke verzorging $\quad 0.75$

MDGO uiterlijke verzorging UV $\quad 0.86$ 
MDGO verpleging VP

INTAS 1-jarig

Opleiding tot verpleegkundige

Opleiding verpleegkundige maatschappelijke gezondheidszorg

Opleiding tot verpleegkundige met vrijstelling

VHBO

$\begin{array}{ll}\text { KMBO administratie } & 0.55 \\ \text { MMO detailhandelschool } & 0.54 \\ \text { MEAO commercieel } & 0.56 \\ \text { MEAO secretariaats } & 0.54 \\ \text { MEAO vrije richting } & 0.55 \\ \text { MDGO sociale arbeid SA } & 0.51 \\ \text { INTAS 1-jarig } & 0.58 \\ \text { HAVO/MBO } & 0.70 \\ \text { MAVO } & 0.51 \\ \text { HAVO } & 0.68 \\ \text { WWO } & 0.52\end{array}$

MEAO bedrijfsadministratief

KMBO administratie

MMO detailhandelschoo

0.61

MEAO commercieel

0.71

MEAO bestuurlijk

0.56

MEAO secretariaats

0.59

MEAO vrije richting

MEAO commercieel

LEAO kantoorpraktijk

KMBO administratie

MMO detailhandelschool

MEAO bedrijfsadministratief

MEAO bestuurlijk

MEAO secretariaats

MEAO vrije richting

MEAO logistiek

MEAO commercieel/secretariaats

MEAO bank- en verzekeringswezen

VHBO

MEAO bestuurlijk

KMBO administratie

MMO detailhandelschool

MEAO bedrijfsadministratief

MEAO commercieel

MEAO secretariaats

MEAO vrije richting

MEAO logistiek 
MEAO secretariaats

$\begin{array}{ll}\text { KMBO administratie } & 0.79 \\ \text { MMO detailhandelschool } & 0.60 \\ \text { MEAO bedrijfsadministratief } & 0.59 \\ \text { MEAO commercieel } & 0.80 \\ \text { MEAO bestuurlijk } & 0.69 \\ \text { MEAO vrije richting } & 0.75 \\ \text { MEAO directie-secretariaat } & 0.78 \\ \text { MEAO commercieel/secretariaats } & 0.68 \\ \text { VHBO } & 0.54 \\ \text { Opleiding tot vertaler } & 0.62\end{array}$

MEAO vrije richting

$\begin{array}{ll}\text { LEAO kantoorpraktijk } & 0.55\end{array}$

KMBO administratie $\quad 0.86$

MMO detailhandelschool $\quad 0.65$

$\begin{array}{ll}\text { MEAO bedrijfsadministratief } & 0.70\end{array}$

$\begin{array}{ll}\text { MEAO commercieel } & 0.87\end{array}$

$\begin{array}{ll}\text { MEAO bestuurlijk } & 0.74\end{array}$

MEAO secretariaats $\quad 0.75$

MEAO logistiek $\quad 0.56$

MEAO commercieel/secretariaats $\quad 0.52$

MEAO bank- en verzekeringswezen $\quad 0.60$

MDGO sociale arbeid SA $\quad 0.51$

$\begin{array}{ll}\text { VHBO } & 0.55\end{array}$

MMO detailhandelschool: branchedifferentiatie MMO-BD

\begin{tabular}{ll} 
LHNO verzorgende beroepen & 0.76 \\
\hline$H N O$ textelenst
\end{tabular}

$\begin{array}{ll}\text { LHNO textielverwerkende beroepen } & 0.78\end{array}$

$\begin{array}{ll}\text { LHNO uiterlijke verzorging } & 0.52\end{array}$

LHNO kantoor/verkooppraktijk $\quad 0.92$

$\begin{array}{ll}\text { LMO } & 0.87\end{array}$

LEAO kantoorpraktijk $\quad 0.82$

LEAO winkelpraktijk $\quad 0.86$

AVMB algemene vorming op maatschappij en beroep 0.88

$\begin{array}{ll}\text { KMBO detailhandel } & 0.92\end{array}$

MTO fijnmechanische techniek $\quad 0.73$

$\begin{array}{ll}\text { MMO detailhandelschool (MMO-C) } & 0.95\end{array}$

MDGO civiel \& consumptieftechnische diensten $\quad 0.66$

$\begin{array}{ll}\text { MDGO mode en kleding MK } & 0.95\end{array}$

MDGO mode en kleding: realisatie MK (MK/R) $\quad 0.93$

MDGO mode en kleding: commercieel MK (MK/C) $\quad 0.95$

MDGO mode en kleding: presentatie MK (MK/P)

MDGO uiterlijke verzorging: ondernemer schoonheids- en voetverzorging 0.78

MDGO uiterlijke verzorging: ondernemer schoonheidsverzorging UV (UV/OS) 0.66

$\begin{array}{ll}\text { MAVO } & 0.71\end{array}$

$\begin{array}{ll}\text { MAVO-4 } & 0.80\end{array}$ 
HAVO $\quad 0.75$

WWO $\quad 0.79$

Vormgeving metalen en kunststoffen $\quad 0.54$

Opleiding praktijkdiploma directie, harmonie en fanfare $\quad 0.66$

MMO detailhandelschool (MMO-C)

LAO land- en tuinbouw: bloemsierkunst $\quad 0.54$

\begin{tabular}{ll} 
LHNO verzorgende beroepen & 0.54 \\
\hline
\end{tabular}

LHNO textielverwerkende beroepen $\quad 0.77$

$\begin{array}{ll}\text { LHNO uiterlijke verzorging } & 0.52\end{array}$

LHNO kantoor/verkooppraktijk $\quad 0.92$

$\begin{array}{ll}\text { LMO } & 0.87\end{array}$

$\begin{array}{ll}\text { LEAO kantoorpraktijk } & 0.83\end{array}$

LEAO winkelpraktijk $\quad 0.86$

AVMB algemene vorming op maatschappij en beroep $\quad 0.88$

$\begin{array}{ll}\text { KMBO detailhandel } & 0.92\end{array}$

$\begin{array}{ll}\text { MTO fijnmechanische techniek } & 0.73\end{array}$

MMO detailhandelschool $\quad 0.54$

MMO detailhandelschool: branchedifferentiatie MMO-BD 0.95

MDGO sociale arbeid SA $\quad 0.51$

MDGO civiel \& consumptieftechnische diensten $\quad 0.65$

$\begin{array}{ll}\text { MDGO mode en kleding MK } & 0.93\end{array}$

MDGO mode en kleding: realisatie MK (MK/R) $\quad 0.92$

MDGO mode en kleding: commercieel MK (MK/C) 0.94

MDGO mode en kleding: presentatie MK (MK/P) $\quad 0.94$

MDGO uiterlijke verzorging: ondernemer schoonheids- en voetverzorging 0.78

MDGO uiterlijke verzorging: ondernemer schoonheidsverzorging UV (UV/OS) 0.65

$\begin{array}{ll}\text { MAVO } & 0.72\end{array}$

$\begin{array}{ll}\text { MAVO-4 } & 0.79\end{array}$

HAVO $\quad 0.78$

$\begin{array}{ll}\text { WWO } & 0.81\end{array}$

Vormgeving metalen en kunststoffen $\quad 0.53$

Opleiding praktijkdiploma directie, harmonie en fanfare $\quad 0.65$

MMO horeca

KMBO horeca $\quad 0.51$

MMO detailhandelschool $\quad 0.58$

MMO toerisme $\quad 0.53$

$\begin{array}{ll}\text { WWO gymnasium } & 0.71\end{array}$

MMO toerisme

MMO detailhandelschool $\quad 0.66$

$\begin{array}{ll}\text { MMO horeca } & 0.53\end{array}$

$\begin{array}{ll}\text { MTRO } & 0.69\end{array}$ 


\section{Bijlage 3 Indeling opleidingen naar segment ${ }^{21}$}

\section{Type 1 Professioneel segment}

LTO Bouwtechniek: stofferen (3)

LTO grafische techniek (5)

LEAO vrije richting (2)

MTO werktuigbouwkunde: besturing (2)

MTO Overig wegenbouw: monteur (7)

MDGO assistente gezondheidszorg: apothekersassistente (AG/AA) (197

MDGO assistente gezondheidszorg: tandartsassistente (AG/TA) (66)

MDGO assistente gezondheidszorg: doktersassistente (AG/DA) (203)

MDGO uiterlijke verzorging: schoonheids- en voetverzorging UV UVISV-VV (13)

INTAS (1)

MDGO activiteitenbegeleiding $A B(156)$

HPO 2e graads combi exact (13)

Ergotherapie (73)

Fysiotherapie (252)

Logopedie (96)

Publiciteits- c.q. grafische vormgeving (42)

Welzijnsbeleid (4)

Theorie der muziek (1)

Expressie door woord en gebaar (9)

HAS tuin- en landschapsinrichting (27)

HNO Gas- \& Petroleumtechnologie (8)

Beroepskeuzewerk (30)

HTO Planologie (6)

HNO Hydrografie (8)

Bejaardenwelzijnswerk (10)

HNO Vliegtuigoperatie (8)

HAS levensmiddelentechnologie (98)

HAS tropische landbouw (10)

Directie koor, orkest of harmonie en fanfare (1)

Agrarische techniek 2e graad (3)

Plantenteelt en -verwerking $2 \mathrm{e}$ graad (19)

HTO Chemische technologie (79)

HTO Milieukunde (24)

Compositie / electronische muziek (1)

HNO Maritiem officier (26)

HGZO opleiding van kader in de gezondheidszorg (9)

HEAO Belastingen (BL) (fiscale economie) (32)

Diëtetiek (67)

HPO leraar basis- en speciaal onderwijs (610)

Creatieve therapie (34)

HEAO Communicatie (44)

HAS Agrarische bedrijfskunde (41)

21. De gevormde clusters zijn onderverdeeld in type 2, 3 of 4 . De opleidingen die niet geclusterd zijn, zijn onderverdeeld in type 1 en type 5 . Het aantal respondenten in het analysebestand staat vermeld tussen haakjes (Bron: RUBS 93 en HBO-Monitor 93). 
Vervolg type 1

HPO 2e graads combi maatschappij (33)

Bibliotheek en documentaire informatie (BDI) (83)

Cultureel werk (17)

Journalistiek (97)

Industriële vormgeving (23)

\section{Type 2 Vakspecifiek segment}

* LAO land- en tuinbouw: dierenhouderij (3) KMAO landbouw (6)

MAS-A: landbouw (43)

MAS-B: landbouw (40)

* LAO land- en tuinbouw: bloemsierkunst (10)

LAO land- en tuinbouw (111)

MAS-A: tuinbouw (75)

MAS-B: tuinbouw (75)

* LAO land- en tuinbouw: groenvoorziening (3) KMAO tuinbouw (10)

* HAS cultuurtechniek: land-, water-, milieubeheer (48) HAS milieukunde (26)

* LTO bouwtechniek (188)

LTO bouwtechniek: timmeren (5)

KMBO bouw- en houtbewerking (19)

* LTO bouwtechniek: schilderen (5)

KMBO bouw- en houtbewerking: schilderen (1)

* MTO bouwkunde (116)

HTO Bouwkunde (98)

* LTO electrotechniek (93)

KMBO electrotechniek (43)

MTO electrotechniek (196)

MTO electrotechniek: energietechniek (10)

* MTS electrotechniek: besturingstechniek (5)

MTO procestechniek (14)

MAS-B: levensmiddelen technologie (3)

* HTO Elektrotechniek (288)

HTO Hogere informatica (43)

HTO Informatica (informatica + informatiekunde) (12)

HEAO Bedrijfsinformatica (BI) (136) 
vervolg type 2

* LTO installatietechniek (20)

KMBO installatietechniek (12)

MTO werktuigbouwkunde: installatietechniek (2)

* LTO mechanische techniek (162)

KMBO metaalbewerking (24)

* LTO Mechanische techniek: autoschade herstellen (4)

LTO Motorvoertuigentechniek (98)

LTO Motorvoertuigentechniek: landbouwwerktuigen (3)

LTO overige opleidingen: dieselmotormontage (13)

KMBO motorvoertuigentechniek (30)

MTO motorvoertuigentechniek (50)

MTO motorvoertuigentechniek: vervolgopleiding (VMVT) (11)

* MTO weg- en waterbouwkunde (38)

HTO Weg-en waterbouwkunde (CT) (83)

* MTO werktuigbouwkunde (162)

HTO werktuigbouwkunde (305)

* MTO Overig wegenbouw: machinist (10)

MTO Overig wegenbouw: techniek (8)

* LTO Consumptieve techniek (32)

LTO Consumptieve techniek: algemeen (8)

LTO Consumptieve techniek: koken (16)

KMBO horeca (14)

MDGO civiel \& consumptieftechnische diensten CCD (15)

MDGO civiel \& consumptieftechnische diensten CCD: consumptieftechnische diensten (CCD/CT) (64)

* LTO Consumptieve techniek: brood (6)

KMBO Consumptieve techniek (6)

KMBO Consumptieve techniek: brood (1)

MMO Bakkerij (20)

* HTO Materiaalkunde (6)

HTO Technische natuurkunde (22)

* HTO Verkeerskunde (19)

HTO Verkeerstechniek (8)

* MLO: biologisch (6)

HLO Biologische laboratoriumopleiding (23)

* MLO/KMLO: biologisch (5)

MLO: medisch (31)

HLO Medische laboratoriumopleiding (94) 
vervolg type 2

* MLO KMLO: chemisch (30)

MLO: chemisch (61)

MAS-A: levensmiddelen technologie (20)

HLO Chemische laboratoriumopleiding (154)

* MLO/KMLO: laboratoriumtechniek (2)

MLO: laboratoriumtechniek (2)

HAS Laboratoriumtechniek (20)

* LNO binnenvaartschool (9)

MNO visserijschool: opleiding SW V (2)

* KMBO verzorgende beroepen (121)

MDGO verzorging VZ (923)

* MDGO sociale arbeid SA (19)

MDGO sociale arbeid: sociale dienstverlening SA (SA/SD) (18)

* Personeelswerk opleidingen (14)

Personeelswerk (136)

Arbeidsvoorzieningen (49)

* MDGO agogisch werk AW (128)

MDGO agogisch werk: agogisch werk AW (AW) (14)

MDGO agogisch werk: (semi-)residentieel AW (AW/RW) (323)

MDGO agogisch werk: cultureel werk AW (AW/CW)' (21)

* MDGO sport \& beweging SB (97)

HPO 1e graads lichamelijke oefening (10)

* LHNO uiterlijk verzorging (45)

LHNO vrije studierichting (6)

LHNO huishoudkunde (2)

KMBO uiterlijke verzorging (23)

MDGO uiterlijke verzorging UV (34)

MDGO uiterlijke verzorging: haarverzorging UV (UV/HV) (34)

MDGO uiterlijke verzorging: vakbekwaamheid dames- en herenkappen UV (UV/NDH) (18)

* MDGO verpleging VP (127)

Opleiding tot verpleegkundige (466)

Opleiding verpleegkundige: maatschappelijke gezondheidszorg (125)

Opleiding tot verpleegkundige met vrijstelling (29)

* HEO accountancy AC (50)

HEAO Bedrijfseconomie (BE) (571)

WWO atheneum (48) 
vervolg type 2

* HEAO Bestuurskunde (BS) (28)

Openbaar bestuur (18)

* Toegepaste huishoudwetenschappen (128)

Hoger hotelonderwijs (208)

* HTO Technische vervoerskunde (20)

HTO Logistiek (management) (32)

HEAO Haven- en vervoerskunde (HV) $(20)$

HEAO Hoger distributie onderwijs (Small Business) (56)

* MTRO (13)

MMO toerisme (29)

* Hoger toerisme \& recreatie: ondernemer (19)

Hoger toerisme \& recreatie: manager (3)

Hoger toerisme \& recreatie: reisbureau (40)

Hoger toeristisch en recreatief onderwijs (71)

HEAO Vrijetijdskunde (19)

* Opleiding leraar VO 1e graads tekenen (12)

HPO 2e graads combi expressie (29)

* HPO 2e graads combi exact \& maatschappij (12)

HPO 2e graads combi combi (3)

Dierhouderij en -verwerking $3 e$ graad (10)

Plantenteelt en -verwerking $3 e$ graad (11)

Veehouderij en -verwerking 2e graad (19)

* HPO 2e graads combi taal (24)

HPO 2e graads combi taal \& maatschappij (20)

* Opleiding getuigschrift muziekonderwijs A-(amv) (2)

Opleiding getuigschrift muziekonderwijs B-schoolmuziek (11)

* Opleiding praktijkdiploma directie, harmonie en fanfare (1)

Docerend musicus (31)

Uitvoerend musicus (13)

* Modevormgeving (24)

Textiele vormgeving (8)

* Architectonische vormgeving (18)

Vormgeving metalen en kunststoffen (3)

* Monumentale vormgeving (9)

Schilderkundige vormgeving / grafiek (8)

* Uitvoerende dramabeoefening (2)

Opleiding docentschap drama (3)

* Opleiding docentschap dans (5)

Uitvoerende dansbeoefening (2) 


\section{Type 3 Generieke segment}

* HAS bosbouw: bos \& natuurbeheer (20)

HAS landbouw (250)

HAS tuinbouw (66)

Agrarische techniek $3 e$ graads (7)

HAS internationale agrarische handel (26)

* HNO Algemene operationele technologie (61)

HTO Autotechniek (59)

HTO Bedrijfskunde (174)

* Inrichtingswerk (88)

Jeugdwelzijnswerk (199)

Maatschappelijk werk (126)

Opleiding leraar VO 1e graads handvaardigheid (4)

Creatief-educatief werk (69)

* HEAO Commercieel (549)

HEAO Economisch-linguistische opleiding (EL) (202)

HTO Technisch-commerciële confectiekunde (16)

\section{Type 4 Niet-specifiek segment}

* MEAO bedrijfsadministratief (355)

MEAO commercieel (167)

MEAO bestuurlijk (26)

MEAO secretariaats (351)

MEAO vrije richting (89)

MEAO logistiek (22)

MEAO directie-secretariaat (9)

MEAO commercieel/secretariaats (6)

MEAO bank- en verzekeringswezen (8)

KMBO administratie (175)

MMO detailhandelschool (17)

Opleiding tot vertaler (36) 
vervolg type 4

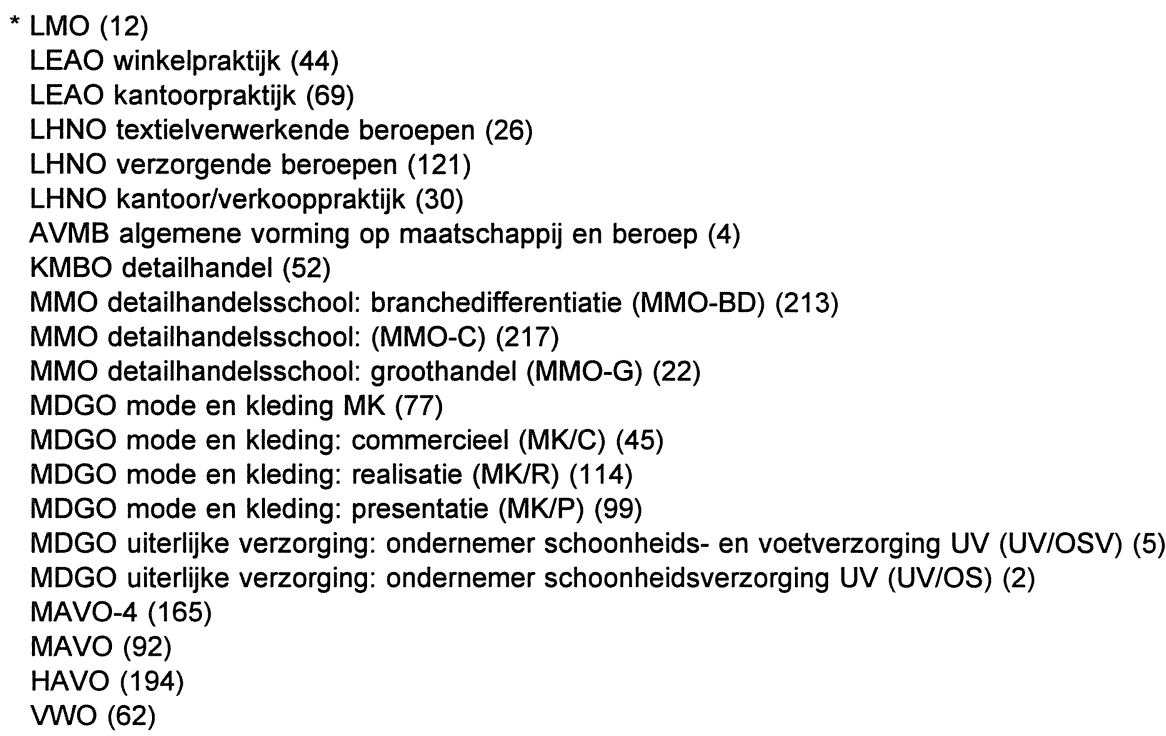

\section{Type 5 Restcategorie}

* INTAS 1-jarig $(7)^{22}$

VHBO (36)

HAVO/MBO (41)

LBO MAVO (11)

MDGO civiel \& consumptieftechnische diensten: civiele diensten CCD (CCD/CD) (21)

VBO GGA (Gemengd Geprofileerde afstudeerrichting (10)

KMBO orientatie/schakel (16)

LAO technologie: levensmiddelentechnologie (4)

MDGO sociale arbeid: arbeidszaken / personeelswerving SA (SA/AP) (20)

HEAO Economisch-juridische opleiding (EJ) (167)

Boekhandel en uitgeverij (16)

MTO fijnmechanische techniek (16)

LHNO textielverwerking en verkoop (1)

MDGO civiel \& consumptieftechnische diensten: consumptieftechnische diensten CCD (CCD)' (2)

MMO horeca (99)

WWO gymnasium (3)

LTO overige opleidingen: theoretisch/technisch TTO (1)

Keramische vormgeving (1)

Agrarische economie (2)

Opleiding leraar VO 1e graads textiele werkvormen (1)

22. Op inhoudelijke gronden is dit cluster ondergebracht bij type 5 . 



\section{Bijlage 4 Clusters van opleidingen in het middelbaar beroepsonderwijs ${ }^{23}$}

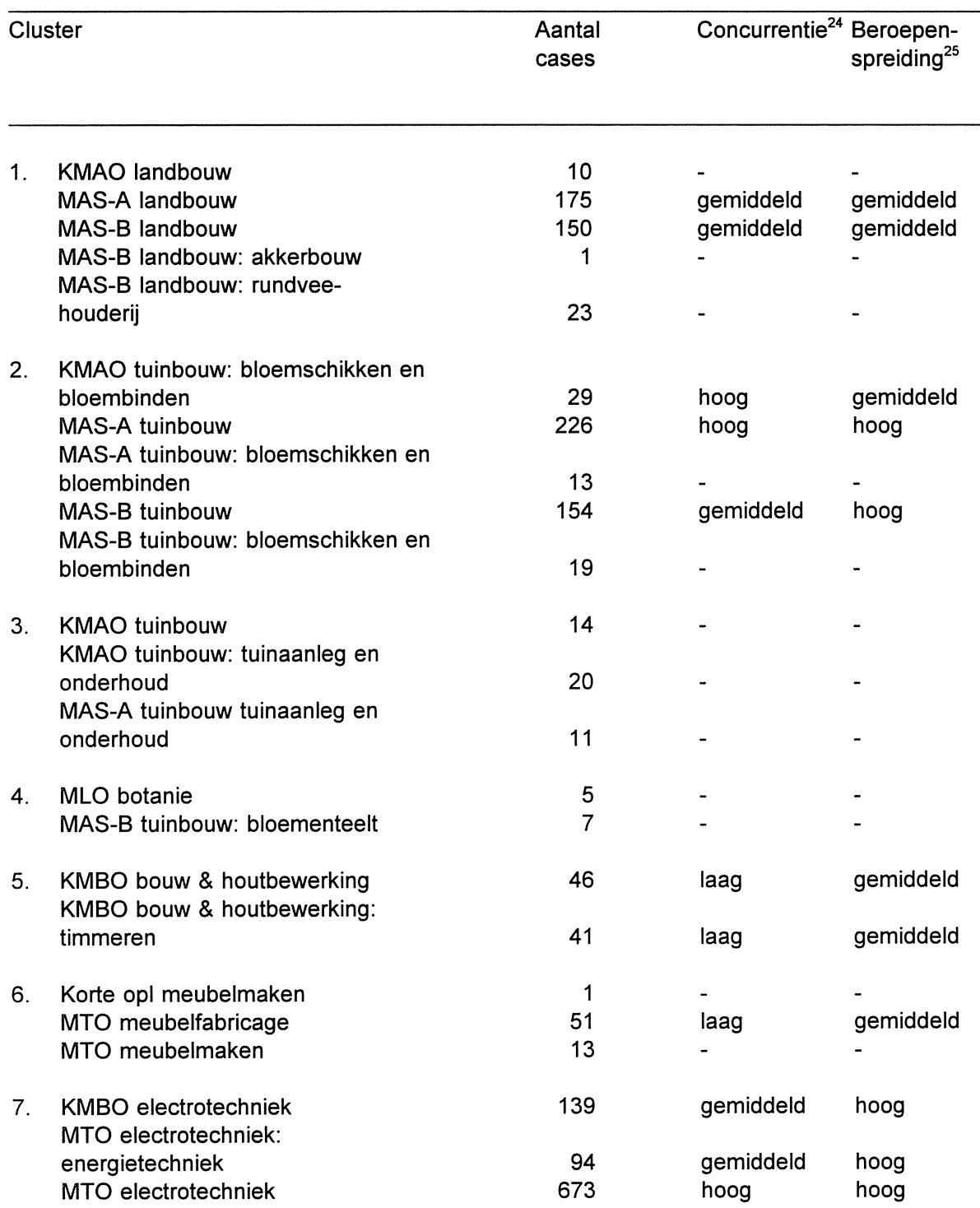

23. Bron: RUBS 92, 93 en 94.

24. Uitsluitend voor opleidingen met meer dan 25 waarnemingen in het bestand.

25. Uitsluitend voor opleidingen met meer dan 25 waarnemingen in het bestand. 
8. MTS fijnmechanische techniek + metaal-A

MTS fijnmechanische techniek + metaal-B

\section{6}

4

9. KMBO motorvoertuigen-

techniek

MTO motorvoertuigentechniek

MTO motorvoertuigentechniek:

vervolgopleiding (VMVT)

10. KMBO procestechniek

MTO procestechniek

MAS-B levensmiddelen-

technologie

11. MTO weg-en waterbouwkunde

MTO weg- en waterbouwkunde: weg-

en waterbouwkunde

12. MTO werktuigbouwkunde:

besturingstechniek

MTO combinatievariant werktuig-

bouwkunde \& electrotechniek

13. KMBO consumptieve techniek

KMBO consumptieve techniek:

brood \& banket

MMO: bakkerij

14. KMBO consumptieve techniek:

kok/kelner

$\mathrm{KMBO}$ instellingskok

$\mathrm{KMBO}$ horeca

KMBO horeca: koken

MDGO civiel \& consumptieftechnische

diensten: consumptief technische

diensten (CT)

MDGO civiel \& consumptieftechnische

diensten

15. MTO goudsmeden

MTO juwelier/goudsmid

MTO goud- en zilversmeden

16. MTO grafisch techniek

MTO grafisch techniek:

admin.- economische
87

133

laag

gemiddeld

gemiddeld

41

gemiddeld

gemiddeld

2

91

6

150

$-$

laag

gemiddeld

laag

hoog

9

9

1

6

15

20

8

7

39

7

178

gemiddeld hoog

47

hoog

hoog

17

49

21

11

10 


\begin{tabular}{|c|c|c|c|c|}
\hline \multicolumn{2}{|c|}{ Cluster } & \multirow{2}{*}{$\begin{array}{r}\begin{array}{r}\text { Aantal } \\
\text { cases }\end{array} \\
20\end{array}$} & \multirow{2}{*}{$\begin{array}{l}\text { Concurrentie } \\
-\end{array}$} & \multirow{2}{*}{$\begin{array}{l}\text { Beroepen- } \\
\text { spreiding }\end{array}$} \\
\hline 17. & MTO wegenbouw: machinist & & & \\
\hline & MTO wegenbouw: wegenbouw & 9 & - & - \\
\hline \multirow[t]{2}{*}{18.} & MLO: biologisch & 32 & laag & laag \\
\hline & MLO microbiologie & 11 & - & - \\
\hline \multirow[t]{2}{*}{19.} & MBO/MLO KMLO: chemisch & 59 & gemiddeld & hoog \\
\hline & MLO: chemisch & 178 & laag & gemiddeld \\
\hline \multirow[t]{5}{*}{20.} & MLO/KMLO: medisch & 21 & - & - \\
\hline & MLO: laboratoriumtechniek & 11 & - & - \\
\hline & MLO: medisch & 132 & laag & erg laag \\
\hline & MLO: analytisch chemisch & 21 & - & - \\
\hline & MLO: klinisch chemisch & 16 & - & - \\
\hline \multirow[t]{3}{*}{21.} & MNO visserijschool: & & & \\
\hline & stuurman KHV & 3 & - & - \\
\hline & $\begin{array}{l}\text { MNO zeevaartschool: } \\
\text { stuurman KHV }\end{array}$ & 2 & - & - \\
\hline \multirow[t]{3}{*}{22.} & MDGO sociale arbeid & 34 & erg hoog & hoog \\
\hline & MDGO sociale arbeid: sociale arbeid/ & & & \\
\hline & sociale dienstverlening & 85 & hoog & hoog \\
\hline \multirow[t]{5}{*}{23.} & MDGO agogisch werk & 292 & hoog & hoog \\
\hline & $\begin{array}{l}\text { MDGO agogisch werk: agogisch } \\
\text { werk }(\mathrm{AW})\end{array}$ & 118 & hoog & gemiddeld \\
\hline & MDGO agogisch werk: agogisch werk/ & & & \\
\hline & (semi-)residentieel (AW/RW) & 1120 & hoog & hoog \\
\hline & $\begin{array}{l}\text { MDGO agogisch werk: agogisch werk/ } \\
\text { cultureel werk (AW/CW) }\end{array}$ & 129 & hoog & gemiddeld \\
\hline \multirow[t]{6}{*}{24.} & MDGO assistenten & & & \\
\hline & gezondheidszorg & 162 & laag & gemiddeld \\
\hline & MDGO ass. gezondheidsz: & & & \\
\hline & ass. gezondh.zorg AG (AG) & 19 & - & - \\
\hline & $\begin{array}{l}\text { MDGO ass. gezondheidszorg: } \\
\text { assistenten gezondheidszorg }\end{array}$ & & & \\
\hline & apothekersass. (AG/AA) & 601 & laag & erg laag \\
\hline \multirow{8}{*}{25.} & KMBO uiterlijke verzorging & 54 & hoog & hoog \\
\hline & MDGO uiterlijke verzorging & 199 & gemiddeld & gemiddeld \\
\hline & MDGO uiterlijke verzorging: & & & \\
\hline & uiterlijke verzorging (UV) & 16 & - & - \\
\hline & $\begin{array}{l}\text { MDGO uiterlijke verzorging: } \\
\text { uiterlijke verzorging/ bediende }\end{array}$ & & & \\
\hline & dames- herenkappen (UV/BDH) & 2 & - & - \\
\hline & $\begin{array}{l}\text { MDGO uiterlijke verzorging: } \\
\text { uiterlijke verzorging/ }\end{array}$ & & & \\
\hline & haarverzorging (UV/HV) & 45 & laag & erg laag \\
\hline
\end{tabular}




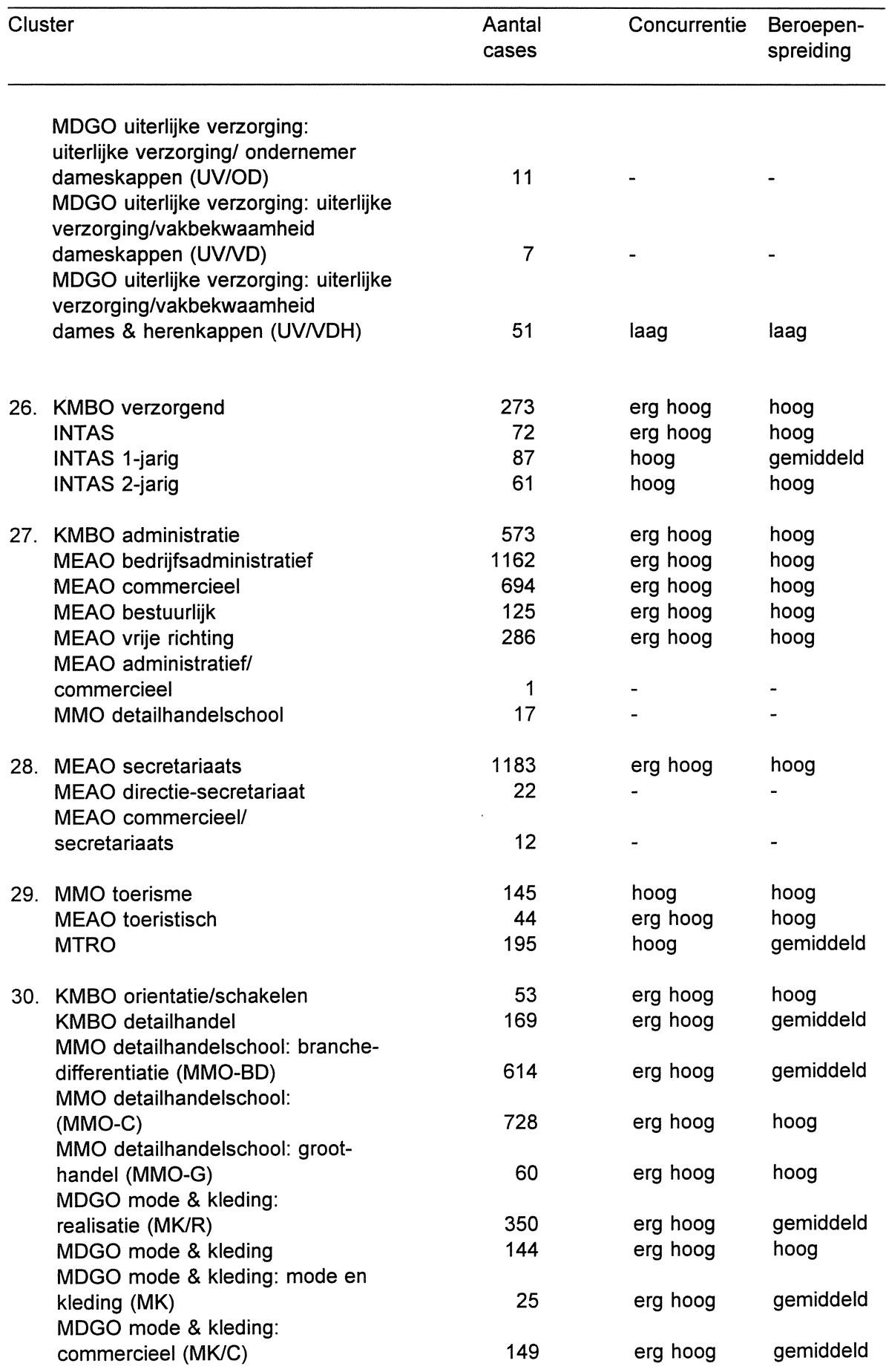




\begin{tabular}{l}
\hline Cluster \\
\hline MDGO mode \& kleding: \\
presentatie (MK/P) \\
MDGO uiterlijke verzorging: \\
schoonheids- \& voetverzorging \\
(UV/SV-VV) \\
MDGO uiterlijke verzorging: \\
ondernemer schoonheids- \& \\
voetverzorging (UV/OSV) \\
MDGO uiterlijke verzorging: \\
ondernemer schoonheids- \\
verzorging (UV/OS) \\
MDGO uiterlijke verzorging: vak- \\
bekwaamheid schoonheids- en \\
voetverzorging (UVNS-WV) \\
MTO houthandel \\
MTO overig juwelier \\
MTO complete woninginrichting \\
MTO mode \& kleding (MOK) \\
MTO zilversmeden \\
MAS-B tuinbouw: boomteelt
\end{tabular}

$\begin{array}{lll}\begin{array}{l}\text { Aantal } \\ \text { cases }\end{array} & \text { Concurrentie } & \begin{array}{l}\text { Beroepen- } \\ \text { spreiding }\end{array}\end{array}$

$\begin{array}{rll}353 & \text { erg hoog } & \text { gemiddeld } \\ 29 & \text { hoog } & \text { gemiddeld } \\ & & \\ 33 & \text { erg hoog } & \text { gemiddeld } \\ & & \\ 21 & - & - \\ & & \\ 10 & - & - \\ 5 & - & - \\ 13 & - & - \\ 80 & \text { erg hoog } & \text { hoog } \\ 39 & \text { erg hoog } & \text { hoog } \\ 9 & - & - \\ 4 & - & -\end{array}$

Niet (meer) geclusterd:

KMAO landbouw en veehouderij KMAO handel in tuinprodukten

KMBO bouw- en houtbewerking: metselen

KMBO bouw- en houtbewerking: schilderen

KMBO Installatietechniek

KMBO metaal

$\mathrm{KMBO}$ grafische techniek

KMBO administratie: adm.

KMBO scheepsgezel

Korte opleiding woning-

inrichting

MAS-A landbouw: rundvee-

houderij

MAS-A levensmiddelen techn.

MAS-B landbouw: intensieve

veehouderij

MAS-B tuinbouw: groenteteelt

MAS-B tuinbouw: tuinaanleg en

onderhoud

MTO bouwkunde

MTO computerkunde vv-cursus

MTO informatica

MTO electrotechniek: commerciële

techniek

$\begin{array}{rll}8 & - & - \\ 3 & - & - \\ 3 & - & - \\ & & \\ 10 & - & - \\ 44 & \text { laag } & \text { hoog } \\ 108 & \text { gemiddeld } & \text { hoog } \\ 27 & \text { erg laag } & \text { hoog } \\ 12 & - & - \\ 1 & - & - \\ 1 & - & - \\ 2 & - & - \\ 42 & \text { hoog } & \text { hoog } \\ 1 & - & - \\ 6 & - & - \\ 17 & - & - \\ 416 & \text { gemiddeld } & \text { hoog } \\ 8 & - & - \\ 18 & - & - \\ 1 & - & -\end{array}$




\begin{tabular}{|c|c|c|c|}
\hline Cluster & $\begin{array}{l}\text { Aantal } \\
\text { cases }\end{array}$ & Concurrentie & $\begin{array}{l}\text { Beroepen- } \\
\text { spreiding }\end{array}$ \\
\hline \multicolumn{4}{|l|}{ MTO electrotechniek: } \\
\hline electronica & 137 & hoog & hoog \\
\hline $\begin{array}{l}\text { MTS electrotechniek: besturings- } \\
\text { techniek }\end{array}$ & 10 & - & - \\
\hline $\begin{array}{l}\text { MTS electrotechniek: } \\
\text { meettechniek }\end{array}$ & 4 & - & - \\
\hline \multicolumn{4}{|l|}{ MTS electrotechniek: } \\
\hline MTO fijnmechanische techniek & 43 & hoog & hoog \\
\hline MTS metaal-A & 1 & - & - \\
\hline MTO metaalkunde & 5 & - & - \\
\hline \multicolumn{4}{|l|}{ MTO motorvoertuigentechniek: } \\
\hline MTO motorvoertuigentechniek & 12 & - & - \\
\hline \multicolumn{4}{|l|}{ MTO motorvoertuigentechniek: } \\
\hline MTO optiek & 35 & erg laag & erg laag \\
\hline MTO uurwerktechniek & 13 & - & - \\
\hline \multicolumn{4}{|l|}{ MTO weg- en waterbouwkunde: } \\
\hline MTO werktuigbouwkunde & 675 & gemiddeld & hoog \\
\hline \multicolumn{4}{|l|}{ MTO werktuigbouwkunde: } \\
\hline \multicolumn{4}{|l|}{ MTO werktuigbouwkunde: } \\
\hline produktietechnieken & 1 & - & - \\
\hline \multicolumn{3}{|l|}{ MTO werktuigbouwkunde: } & - \\
\hline \multicolumn{4}{|l|}{ MTO werktuigbouwkunde: } \\
\hline MTO werktuigbowkunde: theorie & 5 & - & - \\
\hline \multicolumn{4}{|l|}{ MTO grafische techniek: grafisch/ } \\
\hline \multicolumn{4}{|l|}{ MTO grafisch techniek: esthetisch/ } \\
\hline MTO graveren (GR) & 11 & - & - \\
\hline MTO machinale timmerfabricage & 6 & - & - \\
\hline MTO wegenbouwkunde: monteur & 8 & - & - \\
\hline MTO meubelstofferen & 1 & - & - \\
\hline MTO overig: reproductietechn. & 30 & laag & gemiddeld \\
\hline MLO/KMLO: biologisch & 5 & - & - \\
\hline MLO/KMLO: laboratoriumtechn. & 11 & - & - \\
\hline \multicolumn{4}{|l|}{ MNO binnenvaartschool: } \\
\hline baggerbedrijf & 3 & - & - \\
\hline MNO visserijschool: (SW V) & 3 & - & - \\
\hline MNO visserijschool: (SW VI) & 1 & - & - \\
\hline MNO zeevaartschool & 47 & laag & hoog \\
\hline MNO zeevaartschool: SWK/KHV & 6 & - & - \\
\hline MNO maritiem officier & 4 & - & - \\
\hline $\begin{array}{l}\text { MNO scheepswerktuigkundige A } \\
\text { (SWK-A) }\end{array}$ & 16 & - & - \\
\hline
\end{tabular}




\begin{tabular}{|c|c|c|c|}
\hline Cluster & $\begin{array}{l}\text { Aantal } \\
\text { cases }\end{array}$ & Concurrentie & $\begin{array}{l}\text { Beroepen- } \\
\text { spreiding }\end{array}$ \\
\hline MNO operationele techniek & 6 & - & - \\
\hline MMO horecaschool & 287 & hoog & hoog \\
\hline $\begin{array}{l}\text { MMO detailhandelsschool: } \\
\text { internationale handel }\end{array}$ & 8 & & \\
\hline MEAO logistiek & 77 & hoog & hoog \\
\hline $\begin{array}{l}\text { MEAO bank- en } \\
\text { verzekeringswezen }\end{array}$ & 8 & - & - \\
\hline MDGO verzorging VZ & 2486 & hoog & hoog \\
\hline $\begin{array}{l}\text { MDGO sociale arbeid: } \\
\text { sociale arbeid (SA) }\end{array}$ & 4 & - & - \\
\hline $\begin{array}{l}\text { MDGO sociale arbeid: sociale } \\
\text { arbeid/arbeidszaken en } \\
\text { personeelswerk (SA/AP) }\end{array}$ & 72 & hoog & hoog \\
\hline $\begin{array}{l}\text { MDGO ass. gezondh.zorg: ass } \\
\text { gezondheidszorg/ doktersass } \\
\text { (AG/DA) }\end{array}$ & 660 & gemiddeld & laag \\
\hline $\begin{array}{l}\text { MDGO ass. gezondheidszorg: } \\
\text { assistenten gezondheidszorg } \\
\text { tandartsassistent (AG/TA) }\end{array}$ & 215 & laag & erg laag \\
\hline $\begin{array}{l}\text { MDGO civiel en consumptiefte } \\
\text { diensten: civiel en comsumpt } \\
\text { technische diensten (CCD) }\end{array}$ & 10 & - & - \\
\hline $\begin{array}{l}\text { MDGO civiel en consumptiefte } \\
\text { diensten: civiel en consumpti } \\
\text { technische diensten/civiele }\end{array}$ & & & \\
\hline diensten (CCD/CD) & 71 & hoog & hoog \\
\hline MDGO activiteitenbegeleiding & 497 & gemiddeld & gemiddeld \\
\hline MDGO sport \& beweging SB & 137 & laag & laag \\
\hline MDGO verpleging VP & 405 & gemiddeld & gemiddeld \\
\hline
\end{tabular}




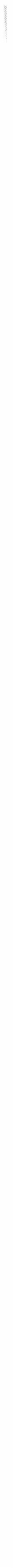




\title{
Bijlage 5 Huidige opleidingsstructuur in het middelbaar beroepsonderwijs ${ }^{26}$
}

\author{
1. MBO-kort \\ landbouw \\ - plantenteelt \\ - veehouderij \\ - levensmiddelentechnologie \\ - groene ruimte \\ - bloemschikken \\ - dierverzorging \\ - paardenhouderij en paardesport \\ - biologisch-dynamische land- en tuinbouw \\ techniek \\ - bouwen \\ - timmeren \\ - metselen \\ - beschermings- en afwerktechnieken \\ - houtbewerking en woninginrichting \\ - meubelmaken en interieurbouw \\ - fijn houtbewerken \\ - medewerker in de woninginrichting \\ - werktuigbouwkunde \\ - installatietechniek \\ - motorvoertuigentechniek \\ - operationele techniek \\ - vliegtuigonderhoudsmonteur \\ - nautische opleidingen \\ - haven en vervoer \\ - schipper/machinist (met beperkt vaargebied) \\ - scheepstechnicus \\ - bakschipper, dekknecht \\ - matroos Rijn- en binnenvaart \\ - stuurman/werktuigkundige zeevisvaart SW6 \\ - elektrotechniek \\ - laboratorium/procestechniek \\ - procestechniek \\ - proefdierverzorging \\ - grafische techniek \\ - conventioneel voorbereiden \\ - electronisch voorbereiden \\ - diepdrukken \\ - flexodrukken \\ - hoogdrukken \\ - offsetdrukken \\ - speciaaldrukken \\ - zeefdrukken
}

26. Bron: Studiegids MBO en Leerlingwezen 1996, Landelijk Dienstverlenend Centrum voor Studie- en Beroepskeuzevoorlichting (LDC), 1995. 
- brocheren

- drukkerijbinden

- standaardbinden

- uitgaafbinden

- vellenbewerken

- in-line machinevoeren

- stansen

- veredelen

- vouwplakken

- brood- en banketbakken

- uitvoerend medewerker ambachtelijk brood- en banketbakkersbedrijf

- uitvoerend medewerker industrieel bakkersbedrijf

- toegepaste vormgeving

- produktiemedewerker goudsmeden

- fijne techniek

- assistent optiek

- atelier uurwerktechnicus

\section{economie}

- administratie

- bedrijfsadminisatrie

- secretariaat

detailhandel

- horeca

- basiskok

- gastheer en gastvrouw

- horeca-medewerker

\section{dienstverlening en gezondheidszorg}

- verzorging

- civiele en consumptieftechnische diensten

- mode en kleding

- modehandel

- uitvoerend medewerker confectie-industrie

- vakman maatkledingbedrijf

- haarverzorging

2. MBO-tussen

\section{landbouw}

- plantenteelt

- veehouderij

- levensmiddelentechnologie

- groene ruimte

- bloemschikken

- dierverzorging

- biologisch en dynamische land- en tuinbouw

- paardehouderij en paardesport

\section{techniek}

- werktuigbouwkunde

- elektrotechniek

- laboratorium/procestechniek

- chemische laboratoriumtechniek

- biologische laboratoriumtechniek

- medische laboratoriumtechniek 
- nautische opleidingen

- stuurman/werktuigkundige kleine schepen

\section{economie}

- horeca

- uitvoerend horeca ondernemer

\section{MBO-lang}

landbouw

- plantenteelt

- veehouderij

- levensmiddelentechnologie

- milieutoezicht

- groene ruimte

- bloemschikken

- dierverzorging

- paardehouderij en paardesport

- biologisch en dynamische land- en tuinbouw

techniek

- bouwkunde

- installatietechniek

- grond- water- en wegenbouw

- geodesie

- metaal

- werktuigbouwkunde

- petroleum-gasonderhoudstechniek

- algemene operationele techniek

- motorvoertuigen en carrosserie

- landbouwwerktuigentechniek

- motorvoertuigentechniek

- bedrijfsmanagement motorvoertuigen

- vliegtuigtechnieken

- vliegtuigbouwkunde

- vliegtuigonderhoudstechnicus (mechanisch)

- vliegtuigonderhoudstechnicus (avionica)

- luchtvaartdienstverlening

- luchtvaartlogistiek

- wegenbouwmachinisten

- fijnmechanische techniek

- instrumenttechniek

- fijne techniek

- optiek

- uurwerktechniek

- metaalkunde

nautische opleidingen

- maritiem officier in de zeevaart

- aankomend schipper Europese binnenwateren

- stuurman werktuigkundige zeevisvaart SW4

- stuurman werktuigkundige zeevisvaart SW5

- haven- en vervoer

- scheepsbouw

- baggeraar machinist

- baggeraar stuurman

- baggeraar 
- elektro

- elektrotechniek

- technische informatica

- vliegtuigelektronicatechniek

- fotonica

- proces- en laboratoriumtechniek

- procestechniek

- medische laboratoriumtechniek

- chemische laboratoriumtechniek

- biologische laboratoriumtechniek

- laboratoriumtechniek

- beschermings- en afwerkingstechniek

- reclame- en presentatietechnieken

- grafische techniek

- grafisch intermediair

- multimedia vormgeven

- bedrijfsvoeren

- technisch creatief

brood en banketbakken

- ondernemer midden- en klein bakkersbedrijf

- productieleider industrieel bakkersbedrijf

- edelsmeden

- goudsmeden

- zilversmeden

- graveren

- juwelier

houtbewerking en woninginrichting

- meubelfabricage

- complete woninginrichting

- meubelmaken

- meubelstofferen

- woningstofferen

- machinale timmerfabricage

- houthandel

economie

- administratie

- bedrijfsadministratie

- secretariaat

- economisch-juridisch

- commerciële dienstverlening

- logistiek

- detailhandel

- horeca

- manager horeca-ondernemer

- uitvoerend horeca-ondernemer

- middelbaar toeristisch- en recreatief onderwijs

- slagerij en vleessector

- ondernemer slagersbedrijf

- leidinggevende vleesverwerkende industrie

- levensmiddelenhandel

- textielhandel

dienstverlening en gezondheidszorg

- dienstverlening en gezondheidszorg 
- aktiviteitenbegeleiding

- sociaal-cultureel werk

- sociaal-pedagogisch werk

- verzorging

- sociaal/juridisch

- sociale dienstverlening

- sociaal/juridische dienstverlening

- arbeidsmarktpolitiek en personeelsbeleid

civiele- en consumptieftechnische diensten

- verpleging

- assisterende beroepen in de gezondheidszorg

- doktersassistent

- tandartsassistent

- apothekersassistent

- uiterlijke verzorging

- haarverzorging

- voetverzorging

- schoonheidsverzorging

- mode en kleding

- breed vakman maatkledingbedrijf

- middenkader medewerker confectie-industrie

ondernemer maatkledingbedrijf

sport en bewegen 